\title{
Car users exposure to particulate matter and gaseous air pollutants in megacity Cairo
}

\author{
Rana Alaa Abbass ${ }^{a}$, Prashant Kumara, ${ }^{a}$, Ahmed El-Gendy ${ }^{b}$
}

${ }^{\mathrm{a}}$ Global Centre for Clean Air Research (GCARE), Department of Civil and Environmental Engineering, Faculty of Engineering and Physical Sciences, University of Surrey, Guildford GU2 7XH, United Kingdom

${ }^{\mathrm{b}}$ Department of Construction Engineering, School of Sciences and Engineering, The American University in Cairo, New Cairo 11835, Egypt

\section{Graphical abstract}
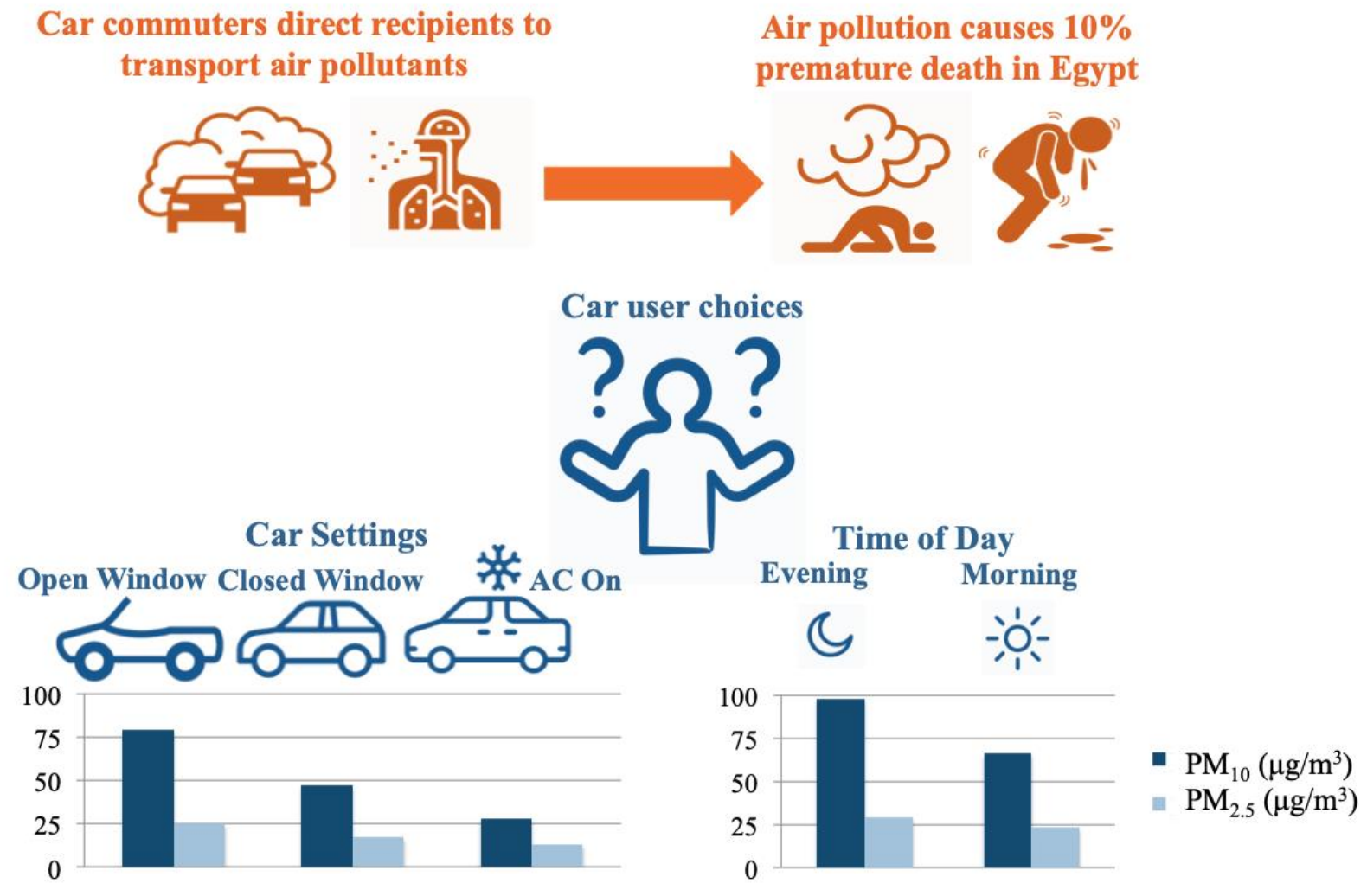

${ }^{1}$ Corresponding author. Global Centre for Clean Air Research (GCARE), Department of Civil and Environmental Engineering, Faculty of Engineering and Physical Sciences, University of Surrey, Guildford GU2 7XH, United Kingdom; E-mail adresses: P.Kumar@surrey.ac.uk, Prashant.Kumar@cantab.net 


\title{
Research highlights
}

- Open windows result in exposure to higher concentrations $\mathrm{PM}_{10}$ and $\mathrm{PM}_{2.5}$.

- Evening peak hours are most congested and cause highest $\mathrm{PM}_{10}$ and $\mathrm{PM}_{2.5}$ pollution.

- Proximity to deserts and road construction works result in $64 \%$ higher $\mathrm{PM}_{10}$ levels.

- Cross-city routes result in 3.6 times higher $\mathrm{PM}_{2.5}$ concentration than inside zones.

- $\mathrm{PM}_{2.5} / \mathrm{PM}_{10}<0.5$ suggests dominance of coarse particles in arid countries as Egypt.

\begin{abstract}
Cars are a dominant mode of transport in megacity Cairo, yet there is a scarcity of personal exposure data on air pollution. This is the first car users exposure study that investigates the underlying factors affecting particulate matter (PM); with aerodynamic diameter $\leq 2.5 \mu \mathrm{m}$ $\left(\mathrm{PM}_{2.5}\right)$ and $\leq 10 \mu \mathrm{m}\left(\mathrm{PM}_{10}\right)$, nitrogen oxides $\left(\mathrm{NO}_{2}\right)$ and carbon monoxide $(\mathrm{CO})$ concentrations across Greater Cairo. Data is collected using a portable monitor during morning and evening peak hours for three car settings (open window; closed window; AC on). Open window consistently resulted in highest $\mathrm{PM}_{10}$ and $\mathrm{PM}_{2.5}$ concentrations $(65 \%$ and $48 \%$ higher than $\mathrm{AC}$ on). However, most Cairo commuters do not have AC and are exposed to levels of $\mathrm{PM}_{10}$ and $\mathrm{PM}_{2.5}$ as high as 227 and $119 \mu \mathrm{g} / \mathrm{m}^{3}$. Evening peak hours experience higher pollution compared to morning peak. Zones with construction activities have $64 \%$ higher $\mathrm{PM}_{10}$ concentrations. $\mathrm{PM}_{2.5}$ levels in cross-city routes are 3.6 times levels in high-activity zones. The derived $\mathrm{PM}_{2.5} / \mathrm{PM}_{10}$ ratios are relatively low $(<0.5)$ indicating a dominance of coarse particles fraction. $\mathrm{AC}$ on resulted in lowest average concentrations of $\mathrm{NO}_{2}$ and highest $\mathrm{CO}$ levels. This study provides preliminary air pollutants exposure mapping for car commuters that aims to feed into control strategies.
\end{abstract}

Keywords: Air pollutant concentrations; Particulate matter; Car commuters; Megacity Cairo; Egypt air pollution; CArE-Cities project

\section{Introduction}

Greater Cairo is the largest urban area in the Middle East and North Africa (MENA) and was ranked the sixth largest city globally in 2018 (Huzayyin and Salem 2013, United Nations 2018). The city is characterized by high congestion due to a population density of $13107 / \mathrm{km}^{2}$ and a car count of 2.4 million (El-Mansy et al. 2013, CAPMAS 2017, Moustafa and Zakey 2018). Urban growth rates are higher than the rate of development of public transport services resulting in the increased use of private vehicles and shared taxis $(73 \%$ of 
the Greater Cairo fleet) (Duquennois and Newman 2009, El-Dorghamy et al. 2015). Car-type vehicles are more flexible and sometimes equally affordable to mass transport causing the modal shift, as shown in SI Figure S1. Air pollution in Cairo is largely attributed to traffic congestion and unregulated control of exhaust emissions from older vehicles (17\% of private cars and 32\% of taxis are over 25 years old) (Chapman 2007, Huzayyin et al. 2009, Waked and Afif 2012, Huzayyin and Salem 2013). Health exposure assessment studies concluded that commuters using motorized transport are direct recipients of concentrations of air pollutants that exceed the World Health Organization (WHO) standards due to their proximity to traffic (Waked and Afif 2012, Cepeda et al. 2017). Particulate matter (PM) with aerodynamic diameter $\leq 2.5 \mu \mathrm{m}\left(\mathrm{PM}_{2.5}\right)$ and $\leq 10 \mu \mathrm{m}\left(\mathrm{PM}_{10}\right)$, nitrogen oxides $\left(\mathrm{NO}_{2}\right)$ and carbon monoxide (CO) have been declared amongst the major health-threatening air pollutants (WHO 2003, Krzyzanowski et al. 2005, Apparicio et al. 2018, Okokon et al. 2018, Requia et al. 2018). PM 2.5 can result from several anthropogenic activities including biomass burning however, the WHO has stated that almost $36 \%$ of atmospheric $\mathrm{PM}_{2.5}$ is attributed to on-road traffic, where $12 \%$ of the daily dose of $\mathrm{PM}_{2.5}$ inhaled by commuters occurs while in traffic (Nasser et al. 2015, Kumar et. al. 2018a, Kumar et al. 2020). In Delhi, for example, it was reported that $80-90 \%$ of $\mathrm{NO}_{\mathrm{x}}$ and CO pollutant emissions are attributed to the transport sector (Hama et al. 2020). In 2018, chronic obstructive pulmonary disease and chronic bronchitis patient admissions to a hospital in Cairo increased by $1.8 \%$ and $2.14 \%$, respectively, following periods of high $\mathrm{PM}_{10}$ incidents (Heger et al. 2018). High PM concentrations cause around 10\% of premature deaths in Egypt, where the national cost of air pollution is estimated at \$20.9 million (Tsiouri et al. 2015, Saade 2016, Heger et al. 2018).

Globally, $\mathrm{PM}_{2.5}$ is perceived as a root cause to numerous health complications where its smaller diameter allows for deeper penetration into the lungs, entering the bloodstream and damaging vital organs (Martins and Carrilho da Graça 2018). Hence there is a need to raise awareness amongst transport pollution recipients to drive informed decision-making (Mahajan et al. 2020). Public awareness about the threats of vehicle induced pollution has compelled policymakers in some countries to progress stringent emissions regulations that forced vehicle manufacturers to install particle filters and drivers to use cleaner fuels (Martins and Carrilho da Graça 2018). Research has also showed that PM emissions were also generated from particles re-suspension in the urban environment, which drove infrastructural changes like maintaining unpaved roads, street cleaning and urban greening (Qiu et al. 2017, Martins and Carrilho da Graça 2018). Greening has proven to add to citizens' awareness of the dynamics 
that affect their lifestyle, which reflected in a wider participation in public decisions that pertain to urban design and a modal shift in transport away from car-based mobility (Ortolani and Vitale 2016; Kumar et al., 2019). Other recorded efforts that aim to reduce air pollution and achieve a sustainable city model include; limiting car use, improving public transport and enhancing facilities that encourage walking and cycling (Hama et al. 2020). Moreover, the advancement in personal air quality monitoring systems allowed for real-time air pollutants data collection that could be coupled with GIS data to feed into commuters' daily decisions, in terms of mode of transport and route selection choices (Pilla and Broderick 2015, Nagendra et al. 2019). Portable air quality monitoring devices, like spatial interpolation techniques, have proven beneficial to low-middle income countries in acquiring data at locations where setting up new monitoring stations is accompanied with financial and logistical obstacles (Shukla et al. 2020). For example, air quality field campaigns have shown that the mean PM concentrations on an urban expressway were 9\%,29\% and 32\% higher than those on an arterial road, a collector road and a local road in China, urging users to avoid highly polluted expressways (Qiu et al. 2017). Furthermore in Belgium, school children who have adopted a suggested cleaner route were exposed to $10 \mu \mathrm{g} / \mathrm{m}^{3}$ less average $\mathrm{NO}_{2}$ concentrations (Ahmed et al. 2020). Ultimately, the United Nation's (UN) Sustainability Development Goals (SDGs) call for citizens' Good Health and Well-being (SDG 3) within Sustainable Cities and Communities (SDG 11) where good air quality is a basic right. A first step in achieving such an aspiration is access to equitable, transparent knowledge (SDG 4, 16) and access to environmental information through viable monitoring techniques that would enhance public knowledge and in turn drive users and policymakers to collaborate for cleaner, safer surroundings (SDG 12, 17).

Research on air pollution carried out for Cairo and MENA is limited and inconsistent (Huzayyin et al. 2009, Abbas et al. 2016). However, Egypt has a fixed air quality-monitoring network with a total of 47 stations in Greater Cairo (Duquennois and Newman 2009, Huzayyin et al. 2009, EEAA 2017). Table 1 shows that most Cairo studies have attempted to quantify concentrations of $\mathrm{PM}_{10}, \mathrm{PM}_{2.5}, \mathrm{NO}_{2}$ and $\mathrm{CO}$ based on data from the monitoring stations for limited amounts of time. Between 1997 and 2004, vehicle exhaust accounted for 32\% of $\mathrm{PM}_{10}$ and $\mathrm{PM}_{2.5}$ pollution levels (El-Dorghamy et al. 2015). In 2006, annual averages of $\mathrm{PM}_{10}$ were observed at $250 \mu \mathrm{g} / \mathrm{m}^{3}$ in industrial zones and $177 \mu \mathrm{g} / \mathrm{m}^{3}$ in residential areas (Huzayyin and Salem 2013). In 2018, the 24-hr average of $\mathrm{PM}_{10}$ ranged between 93 and $221 \mu \mathrm{g} / \mathrm{m}^{3}$ across different residential areas in Greater Cairo (Moustafa and Zakey 2018). It was observed that 
$\mathrm{NO}_{\mathrm{x}}$ and $\mathrm{CO}$ increase along congested streets in Greater Cairo to reach $76 \mu \mathrm{g} / \mathrm{m}^{3}$ and 8.23 $\mathrm{mg} / \mathrm{m}^{3}$, respectively (Huzayyin et al. 2009). The local and regional reviewed studies in Table 1 , reached common findings where PM levels often exceed health standards and that studies are limited and air pollutant inventories are sparse.

There is a lack of use of real-time environmental data collected through field surveys to assess commuters' exposure to air pollutants (Huzayyin et al. 2009). Although there is a large amount of data present for ambient air pollution, research in the area of indoor air quality in vehicles and its impact on health is still limited (Müller et al. 2011). Conventional air quality monitoring is based on static and sparse measurement stations, which fail to capture tempo-spatial heterogeneity and identify pollution hotspots (Kumar et al. 2015). Furthermore, Cairo monitoring stations do not investigate pollutant concentrations at inhalation level. Despite the evident shift towards the reliance on small cars, no car exposure studies have been carried out. For the first time this study focuses on collecting real-time exposure data of concentrations of air pollutants, utilizing the progress in personal micro-scale sensing technologies (Kumar et al. 2015).

The aim of this study is to quantify personal exposure levels, which are key inputs to the development of robust strategies for exposure control (Kumar et. al 2018b). This work presents in-car concentrations of $\mathrm{PM}_{10}, \mathrm{PM}_{2.5}, \mathrm{NO}_{\mathrm{x}}$ and $\mathrm{CO}$ throughout six high-activity zones and a highly congested cross-city route across Greater Cairo under three different car settings (open window, closed window and AC On) during morning peak and evening peak hours. Collected data is then analysed to capture the changes in air pollutants concentrations resulting from the variations in locations, conditions and times. The overall goal is to understand the underlying factors affecting exposure to PM and gaseous pollutants to map preliminary exposure profiles for car commuters across Greater Cairo and ultimately discuss mitigation strategies.

\section{Methodology}

\subsection{Study design}

This study was designed to evaluate car commuters' exposure across six high activity zones and one cross-city route throughout Greater Cairo (Section 2.2). The factors affecting the concentrations of $\mathrm{PM}_{10}, \mathrm{PM}_{2.5}, \mathrm{NO}_{2}$ and $\mathrm{CO}$ within a car microenvironment are investigated. Three car settings are tested; S1 is "open window", S2 is "closed window" with no ventilation and S3 is "AC On" where air conditioning, fan and recirculation were all activated. S1 is most common in Cairo for older cars and shared taxis for fuel saving purposes 
or because the car is not equipped with air conditioning. S2 is only used during cold days in the short winter of Cairo. S3 is typically used in most private cars for most of the year due to high temperatures (Luangprasert et al. 2017). The majority of runs were carried out on weekdays during two high traffic sessions; morning peak hours (MP) and evening peak hours (EP). A few runs were carried out during the weekend in some of the zones to investigate offpeak traffic conditions. Two sessions of baseline runs were carried out as reference; the first was in an out of city location and the second was at a roadside location. A total of 186 runs were carried out, taking 3672 minutes, generating 5654 data points and covering a distance of $1788 \mathrm{~km}$. The car routes (Section 2.3) selected for each zone are meant to simulate a typical trip, driving through a congested main street and a quieter residential area. The cross-city route covers a round trip between the east and west of Greater Cairo. The same routes were repeated for each car setting and time of the day as a preliminary mapping for exposure across the city. The campaign was carried out using a portable air quality monitor with interchangeable sensor heads designated to measure particulate matter and gaseous air pollutant concentrations. The same vehicle was used for all runs. Two non-smoking occupants including the driver were present in all runs and the monitor was placed in the backseat to test car passenger exposure.

\subsection{Description of study area}

Greater Cairo covers a total area of $3085 \mathrm{~km}^{2}$, its population was over 20 million in 2018 and its fleet size is 3.4 million vehicles (United Nations 2018, CAPMAS 2017). Air pollution in Cairo has been mainly attributed to traffic congestion nevertheless, the city's topography, its proximity to the desert and meteorological conditions play a major role in its poor air quality (Parry and Timilsina 2015, Duquennois and Newman 2009, Huzayyin et al. 2009). Geographically, Greater Cairo is bordered from the east by the Mokattam Hills and to the west by the Abu-Rawash Hills and the Western Desert (Hassanien and Abdel-Latif 2008). Meteorologically, the city experiences low annual precipitation between 22-29 $\mathrm{mm}$ and high temperatures between 18 and $45^{\circ} \mathrm{C}$ (Hassanien and Abdel-Latif 2008). Greater Cairo is also characterized by complex road networks composed of highways, public roads, elevated expressways, bridges, flyovers and tunnels that result in frequent congestion and high car restart rates (El-Kadi 2013, Huzayyin and Salem 2013). SI Figure S2 shows the complex road network of the city. Considering the conditions of Greater Cairo and despite other sources of particulate matter contributing to the background concentrations in an area, the traffic exhaust and the resuspension of dust are likely to remain the main source of PM concentrations 
measured during on-road measurements due to the proximity of car commuters to traffic exhaust (Nasser et al. 2015, Kumar et. al. 2018a, Kumar et al. 2020).

\section{$2.3 \quad$ Selection of routes}

In the 1980s, decentralization took place in Cairo causing the emergence of new activity centres, away from Downtown including Heliopolis, El-Mohandesseen and Al-Maadi (Huzayyin et al. 2009). In the 2000s, new centres developed services including banks, universities and residential compounds in two locations; New Cairo and $6^{\text {th }}$ of October City (Huzayyin et al. 2009). Hence these centres were chosen as the six zones of focus in this study; Z1: Heliopolis, Z2: Al-Maadi, Z3: New Cairo, Z4: Downtown, Z5: El-Mohandesseen and Z6: 6th of October City, as indicated in Figure 1. The map shows how the chosen zones are geographically spread out across Greater Cairo between north-east (Z1), south (Z2), east (Z3), centre (Z4 and Z5) and west (Z6). Z1 and Z2 are popular residential and commercial zones; Z4 and Z5 are downtown locations with heavy traffic owed to high population densities. Z3 and Z6 are new settlements, where construction activities are still underway, accompanied by commercial centres, governmental entities and educational establishments to serve the increasing number of inhabitants.

For each zone, the route passes by two segments; a congested main street and a quieter residential area, where their average length ranges are 3-12 $\mathrm{km}$ depending on the relative size of the zone, as illustrated in Figures 2a-f. The routes have been chosen based on the knowledge of the most travelled main streets and the commonly inhabited residential areas. However, Cairo dwellers usually travel between the different zones on a daily basis for work purposes as most people reside in one zone and work in another. Hence, a route was chosen, shown in Figure $2 \mathrm{~g}$, that covers a few of the main cross-city routes including Salah Salem St., $6^{\text {th }}$ of October Bridge, $26^{\text {th }}$ of July Corridor and sections of the Ring Road.

\subsection{Instrumentation}

The same Aeroqual Series 500 Portable Air Quality Sensor was used to collect the parameters of interest along with temperature and humidity readings (AEROQUAL series 500; Aeroqual Limited, Auckland, New Zealand). The monitor was used interchangeably to measure the different air pollutant concentrations where the same sensor head was used to collect $\mathrm{PM}_{10}$ and $\mathrm{PM}_{2.5}$ while two other sensor heads measured $\mathrm{NO}_{2}$ and $\mathrm{CO}$. Readings were taken every one-minute. The used monitor was purchased earlier in 2018 and was hence 
calibrated by the manufacturer and designated solely for the campaign. Aeroqual Series 500 monitors have been widely used in assessment of exposure to transport air pollutants (Lin et al. 2015, McKercher et al. 2017, Apparicio et al. 2018, Embiale et al. 2019). The car used for all runs was a 2011 Peugeot 207sw private car with engine size 1600cc running on gasoline fuel (octane 92). The ventilation settings for all S3 runs were kept constant with AC temperature set to $16^{\circ} \mathrm{C}$ and recirculation on.

\subsection{Data collection and analysis}

Data collection for high-activity zones was taken between April and June 2018 during which weather conditions are within the same range, while cross-city route measurements were taken in early November 2018 after the extreme Cairo heat waves have passed. Peak traffic times were targeted, following the approach adopted in Kumar et. al, 2018b and based on local knowledge of Cairo peak traffic hours (El-Mansy et al. 2013, Soliman et al. 2016), observations during MP and EP were made between 07:00-11:00h (local time) and 16:0020:00h, respectively. For all three car settings (S1, S2 and S3); $\mathrm{PM}_{10}, \mathrm{PM}_{2.5}, \mathrm{NO}_{2}$ and $\mathrm{CO}$ concentrations, along with temperature and humidity, were collected every one-minute using the same Aeroqual Series 500 Portable Air Quality Sensor. Wind speed-readings were also taken for the $\mathrm{S} 1$ runs. Temperature and humidity average and standard deviation measurements for trips across high-activity zones are compiled in SI Table S3. For S1, the average ambient temperature was $29 \pm 1^{\circ} \mathrm{C}$ for $\mathrm{MP}$ and $31 \pm 1^{\circ} \mathrm{C}$ for $\mathrm{EP}$ while the relative humidity was $42 \pm 4 \%$ for MP and $31 \pm 3 \%$ for EP. As indicated by standard deviation, these variations are modest to show any disproportional effect on measurements. Furthermore, extreme weather conditions (high temperatures and dust storms) were avoided. Runs were carried out on weekdays to simulate a typical day for a Cairo commuter. However, for some zones, extra weekend runs were carried out along with baseline runs in out-of-city and roadside locations. The trip time within a zone averaged around seventeen minutes. Only $\mathrm{PM}_{10}$ and $\mathrm{PM}_{2.5}$ concentration measurements were collected for the cross-city route trips where the average time for a round trip was almost three hours. Further information on collected data and route details is summarized in Table 2.

Collected air pollutant concentration data was then compiled and processed to produce mean and standard deviation figures of each zone, car setting and time of day. Bar charts with error bars were produced as well as concentration-time plots for $\mathrm{PM}_{2.5}$ and $\mathrm{PM}_{10}$ data to investigate the determinants of PM variations within a car cabin (Sections 3.1 and 3.2). Concentration 
maps were produced for the cross-city routes to observe PM variations throughout the trip (Section 3.3). PM data was further used to calculate $\mathrm{PM}_{2.5} / \mathrm{PM}_{10}$ ratios (Section 3.4). Gaseous pollutant data was briefly analysed and discussed (Section 3.5). ArcGIS (Esri Inc.) was used for generating the spatial distribution of average PM concentrations for the cross-city route. Route maps (Section 2.3) were generated using STRAVA app (https://www.strava.com/).

\section{Results and Discussion}

\subsection{Overview of PM concentrations}

In order to understand the variations in $\mathrm{PM}_{10}$ and $\mathrm{PM}_{2.5}$ concentrations during the different car settings, time of day and across geographical locations, Figure 3 presents bar charts for each car setting (S1, S2 and S3) showing average $\mathrm{PM}_{10}$ and $\mathrm{PM}_{2.5}$ concentrations for each zone (Z1-Z6) and time of day (MP and EP). S1 results in the highest $\mathrm{PM}_{10}$ and $\mathrm{PM}_{2.5}$ concentrations where open car windows expose passengers to suspended dust and car fumes. $\mathrm{PM}_{10}$ average concentrations for S1 were $42 \%$ and $65 \%$ higher than S2 and S3, respectively, and corresponding average $\mathrm{PM}_{2.5}$ concentrations were $32 \%$ and $48 \%$ higher for $\mathrm{S} 1$ than $\mathrm{S} 2$ and S3. Table 3 lists the number of data points for each run along with average and standard deviation numbers for the $\mathrm{PM}_{10}$ and $\mathrm{PM}_{2.5}$ concentrations. Standard deviation numbers show less notable variations for S2 and S3 versus S1 since having closed windows isolates the transport microenvironment from varying external conditions (Chaney et al. 2017, Okokon et al. 2018). $\mathrm{PM}_{10}$ and $\mathrm{PM}_{2.5}$ concentrations for $\mathrm{S} 2$ are higher than for $\mathrm{S} 3$ due to the removal of PM by the AC filtration system (Kumar et al. 2018b). However, travelling with closed windows (S2) is not feasible in Cairo during most seasons due to high temperatures; also a large portion of the Cairo fleet is not equipped with $\mathrm{AC}$ (S3). Hence, most car commuters must use open window (S1) conditions hence, are exposed to average $\mathrm{PM}_{10}$ and $\mathrm{PM}_{2.5}$ concentrations of 82 and $25 \mu \mathrm{g} / \mathrm{m}^{3}$ when traveling inside high-activity zones. For the cross-city route, $\mathrm{S} 1$ commuters are exposed to even higher average $\mathrm{PM}_{10}(227)$ and $\mathrm{PM}_{2.5}\left(119 \mu \mathrm{g} / \mathrm{m}^{3}\right)$ concentrations.

EP runs yield higher $\mathrm{PM}_{10}$ and $\mathrm{PM}_{2.5}$ concentrations compared to MP runs (Figure 3). For S1 EP hours, the average $\mathrm{PM}_{10}$ and $\mathrm{PM}_{2.5}$ concentrations are $32 \%$ and $19 \%$ higher for $\mathrm{EP}$ compared to MP in high activity zones. S2 and S3 follow the same trend of higher PM concentrations during EP sessions. Higher congestion during EP hours is reflected in longer average trip durations compared to MP trips, of around two minutes in high activity zones and twenty minutes for the cross-city route. 
Geographically, Figure 3 shows that $\mathrm{Z} 3$ has the highest average $\mathrm{PM}_{10}$ concentrations of $146 \pm 87$ $\mu \mathrm{g} / \mathrm{m}^{3}$ during EP S1 conditions. New Cairo is situated in the middle of a desert environment with considerable construction activity and unmaintained bumpy roads, exposing its commuters to higher concentrations of $\mathrm{PM}_{10}$ (Abu-Allaban et al. 2007, Zakey et al. 2008, Lowenthal et al. 2014). Z2 (Maadi) is the second highest polluted zone with average $\mathrm{PM}_{10}$ concentrations of $137 \pm 41 \mu \mathrm{g} / \mathrm{m}^{3}$ for S1 EP runs, since it is situated near the Mokkattam Hills and the Degla desert reserve (Zakey et al. 2008). On the other hand, Figure 3 also shows that the difference between the levels of $\mathrm{PM}_{2.5}$ in $\mathrm{Z} 3$ compared to other zones is not as high as $\mathrm{PM}_{10}$ since $\mathrm{PM}_{2.5}$ is not caused by suspended dust rather by motor vehicle emissions (Abu-Allaban et al. 2007, Zakey et al. 2008, Lowenthal et al. 2014). Traffic congestion is comparable in all high-activity zones hence; $\mathrm{PM}_{2.5}$ levels do not vary considerable between zones. Other sources of PM pollution common to high-traffic roads and motorways, include particles from brake wear, tyres wear and road surface wear, which currently constitute $60 \%$ of $\mathrm{PM}_{2.5}$ and $73 \%$ of $\mathrm{PM}_{10}$ road transport emissions in the UK where in Marylebone Road, London, a breakdown of non-exhaust emissions was estimated as $38 \%$ re-suspended dust, $55 \%$ brake dust and $11 \%$ tyre dust (Harrison et al. 2012, Sommer et al. 2018, Monks et al. 2019). Similarly, for Cairo highactivity zones, tyres and road surface wear would be a major source of PM pollution. SI Table S4 lists average $\mathrm{PM}_{10}$ and $\mathrm{PM}_{2.5}$ concentrations collected from two stationary campaigns; a baseline and a roadside location. Also to put average PM concentrations collected from this campaign into perspective, SI Table S5 lists findings from previous studies carried out in regional cities. Overall, car users traveling across cross-city routes with open windows and during evening peak hours are exposed to highest $\mathrm{PM}_{10}$ and $\mathrm{PM}_{2.5}$ concentrations in reference to scenarios investigated in this study. Commuter knowledge of high pollution routes, zones and times would allow for more informed decisions on when and where to use cars in Greater Cairo. Also community awareness would drive policymakers to adopt mitigation strategies that aim to reduce the overall volume of traffic, lower speed limits in motorways, promote driving behaviour that reduces braking, redirect road traffic away from construction sites, carry out road sweeping, street washing or apply dust suppressants to street surfaces (Amato et al. 2009, Kole et al. 2017, Monks et al. 2019).

\subsection{Temporal variations of PM in high-activity zones}

Figure 4 shows the fluctuations of PM concentrations versus time for the S1 EP case for all zones. Trip durations vary between zones depending on the route and traffic levels. Across all zones, PM concentrations drop towards the end, which represents the residential 
segment of the trip where there is lighter traffic. However for Z3, PM concentrations have increased towards the end of the trip due to the passing of a construction truck loaded with gravel, a common occurrence in New Cairo. PM concentration peaks occur for Z1 due to turbulence and a gust of wind. Z2 has consistently higher concentrations with minimal variations between main streets and residential areas due to the geographical conditions of Maadi (Section 3.1). Z1, Z2 and Z3 demonstrate higher $\mathrm{PM}_{10}$ concentrations compared to the other three zones, which could be due to the season during which data was collected (April experiences Khamaseen dust storms contributing to higher background levels of coarse particles). Furthermore, Z4 and Z5 are situated within the centre of Greater Cairo that has taller buildings and hence, might shelter commuters from dust. Z6 is a relatively new zone similar to $\mathrm{Z} 3$, however, it is located at a higher altitude, has less construction activities and road maintenance is better, resulting in better air quality. Figure $4 \mathrm{~b}$ shows that $\mathrm{PM}_{2.5}$ concentrations vary between $10-70 \mu \mathrm{g} / \mathrm{m}^{3}$ for all zones. For example, Z4, Z5 and Z6 concentrations are not considerably less than the first three zones, as opposed to the case of $\mathrm{PM}_{10}$ concentrations. $\mathrm{PM}_{2.5}$ is less sensitive to ambient and geographical conditions and is proxy of motor vehicle induced pollution, where traffic congestion seems consistent across the studied zones (AbuAllaban et al. 2007, Zakey et al. 2008, Lowenthal et al. 2014). Also it is estimated that 3-7\% of $\mathrm{PM}_{2.5}$ in air globally is a result of tyre wear and tear (a by-product of heavy traffic) contributing to the health burden of air pollution (Kole et al. 2017).

Preliminarily results show $\mathrm{Z} 3$ as a pollution hot spot so we focus on Z3 in Figure 5 to show $\mathrm{PM}_{10}$ and $\mathrm{PM}_{2.5}$ concentration versus time plots for all scenarios. $\mathrm{S} 1$ is consistently higher than the other two settings and S3 results in the least pollution and least fluctuations in PM concentrations due to the isolated microenvironment and the $\mathrm{AC}$ that improves air quality. Moreover, weekend runs show that less traffic results in lower PM concentrations, especially for S1 (Figure 5). Analysing PM concentrations in high-activity zones shows that open windows exposes car users to spikes in PM concentrations caused by pollution inducing events and zones that have construction activities, unmaintained roads (dust re-suspension) and are close to desert environments have higher $\mathrm{PM}_{10}$ concentrations while, high traffic congestion in zones results in increased $\mathrm{PM}_{2.5}$ levels owing to transport emissions as well as tyre and brake dust. The first step in mitigating the impacts of air pollution caused by traffic is controlling emissions at the source, which requires knowledge of emissions concentrations to feed as inputs to the decisions taken by neighbourhood councils responsible for the urban design of high-activity zones. Such information would allow relevant entities to locate zones most in 
need of green areas, green roofs and walls that have proven successful in mitigating atmospheric PM levels (Viecco et al. 2018, Abhijith and Kumar 2019, Kumar et al. 2019, Ottosen and Kumar 2020). Other mitigation mechanisms that can be adopted in high-activity zones are the "odd-even restriction" measure that identifies a certain percentage of the vehicle fleet to travel within the city during different days of the week (Chen et al. 2014, Kumar et al. 2017). Finally creating designated lanes for cyclists and safe pavements for pedestrians to travel within a zone would significantly reduce traffic and in turn result in less PM pollution (United Nations 2013).

\subsection{Tempo-spatial variations of PM over cross-city route}

As was the case for high activity zones (Section 3.1), concentrations of $\mathrm{PM}_{10}$ during EP are consistently higher than MP hours for the cross-city route. Figure 6 depicts concentration maps for EP runs while MP cross-city maps are in SI Figure S6. Moreover, S3 results in the lowest $\mathrm{PM}_{10}$ average concentrations (76\% less than $\mathrm{S} 1$ and $50 \%$ less than $\mathrm{S} 2$ ). Figures 6a-c show higher $\mathrm{PM}_{10}$ concentrations during the return leg (lower segment of the route on the maps) indicated by darker shades as the Ring Road is more exposed to the desert environment compared to the first leg of the trip, which covers an inter-city street and bridge. Moreover, $26^{\text {th }}$ of July Corridor (characterized by a tail in the route as shown in Figures 6a-f) also has high $\mathrm{PM}_{10}$ concentrations since it passes over agricultural lands where there is waste burning. Heavy traffic results in frequent braking hence, brake wear constitutes 16-55\% of non-exhaust trafficrelated $\mathrm{PM}_{10}$ emissions in urban environments while tyre wear contributes 5-30\% (Grigoratos and Martini 2014, Sommer et al. 2018). Figures 6d-f also show that S1 conditions expose car commuters to higher $\mathrm{PM}_{2.5}$ concentrations. Similar to $\mathrm{PM}_{10}$, the return route results in higher $\mathrm{PM}_{2.5}$ concentrations.

Figure 7 shows the variations of $\mathrm{PM}_{10}$ with time over the course of the cross-city route trip, which coincides with the results of concentration maps indicated by darker shades during the return leg. Concentrations during EP trips are consistently higher than during MP trips where the average $\mathrm{PM}_{10}$ concentrations were $240 \pm 117,114 \pm 47$ and $56 \pm 27 \mu \mathrm{g} / \mathrm{m}^{3}$ for $\mathrm{S} 1, \mathrm{~S} 2$ and S3, respectively, while $\mathrm{PM}_{2.5}$ were $99 \pm 34,57 \pm 19$ and $36 \pm 20 \mu \mathrm{g} / \mathrm{m}^{3}$ for S1, S2 and S3, respectively, for EP hours. Overall the highest average concentrations of $\mathrm{PM}_{10}$ resulting from the S1 EP cross-city trips are almost 1.5 times the highest average concentrations of S1 EP trips carried out around high activity zones. Comparison of Figure 7a with Figure 5a shows that the trend variations between the different settings are consistent, however the range of variation and 
levels of concentrations are almost double for the cross-city routes. Also, $\mathrm{PM}_{2.5}$ concentrations are 3.6 times higher for the cross-city route runs compared to high-activity zones. The average travel time within the zones is $10 \%$ of the time taken to travel through the chosen cross-city route and in turn causes an increased exposure to PM pollution. However, Figure $7 \mathrm{~b}$ shows that the concentrations of $\mathrm{PM}_{2.5}$ for the MP trip are higher than during the EP trip for S1, which is not in tune with study observations so far but $\mathrm{PM}_{2.5}$ variations between MP and EP sessions were not as considerable as for $\mathrm{PM}_{10}$. Car passengers have reported fumes associated with bad odour that caused the eyes to water during that MP S1 session in particular, which might have reflected in higher $\mathrm{PM}_{2.5}$ concentrations. This also indicates that conclusions drawn from this study stand in consideration of the pool of circumstances in which the study was conducted. Moreover, traffic in Cairo is to a degree unpredictable and variations in MP versus EP congestion and pollution levels are acceptable. Nevertheless, the traffic load on cross-city routes and exposure to ambient conditions are higher resulting in higher PM concentrations in car cabins. Such observation could be factored in Cairo dwellers' decision on where to work relative to where to live and vice versa (Pilla and Broderick 2015, Nagendra et al. 2019). Also, identifying high pollution routes and times, would support policymakers in directing funds to efficient public mass transport systems in areas that suffer high traffic congestion and encourage car pooling through economic incentives (Orubu 2004, Shrivastava et al. 2013, United Nations 2013). Moreover, it would highlight the urgency of encouraging cleaner fuels, retrofitting vehicle pollution control technologies and applying stringent inspection and maintenance processes that prohibit aged vehicles (Orubu 2004, Shrivastava et al. 2013, United Nations 2013). Possible strategies to control non-exhaust emissions include improving wear properties of materials, cleaning roads and binding dust to road surfaces (Amato et al. 2014).

\section{$3.4 \quad P M_{2.5} / P_{10}$ ratio}

For S1, the average $\mathrm{PM}_{2.5} / \mathrm{PM}_{10}$ ratio combining MP and EP sessions was $0.34 \pm 0.09$ while for $\mathrm{S} 2$ and $\mathrm{S} 3$ the ratio was $0.37 \pm 0.1$ and $0.47 \pm 0.08$, respectively. $\mathrm{PM}_{2.5} / \mathrm{PM}_{10}$ ratios are less than 0.5 for all settings indicating lower contributions of fine particles $\left(\mathrm{PM}_{2.5}\right)$ as compared to coarse particles $\left(\mathrm{PM}_{2.5}-\mathrm{PM}_{10}\right)$. $\mathrm{PM}_{2.5}$ is a proxy of exhaust emissions while $\mathrm{PM}_{2.5-10}$ of nonexhaust contributions (Abu-Allaban et al. 2007, Zakey et al. 2008, Lowenthal et al. 2014), hence, $\mathrm{PM}_{2.5} / \mathrm{PM}_{10}$ ratios less than 0.5 can be attributed to the arid and dry conditions of Greater Cairo (Parry and Timilsina 2015, Duquennois and Newman 2009, Huzayyin et al. 2009). Furthermore, brake and tyre wear contribute considerably to the non-exhaust emissions fraction of coarse particles resulting from heavy traffic in urban areas (Harrison et al. 2012, Grigoratos 
and Martini 2014, Sommer et al. 2018, Monks et al. 2019). Also, the relatively lower ratio exhibited by $\mathrm{S} 1$ compared to $\mathrm{S} 2$ and $\mathrm{S} 3$ could be due to the exposure of the car users to the external environment where coarse particles are a dominant fraction of total PM. The highest average ratio is exhibited by S3 where AC filtration allows for the elimination of a percentage of coarse particles inside a car cabin. The ratios for each scenario are listed in detail in Table 3, the lowest $\mathrm{PM}_{2.5} / \mathrm{PM}_{10}$ ratio (0.2) was observed in $\mathrm{Z} 3$ during EP hours, which could be due to the re-suspension of coarse particles resulting from construction activities and poorly maintained roads (Section 3.2).

The WHO has estimated a $\mathrm{PM}_{2.5} / \mathrm{PM}_{10}$ ratio of 0.35 for arid, desert regions (Li et al. 2010), which coincides with the 0.34 ratio produced by this study for the open window setting. Moreover, a $\mathrm{PM}_{2.5} / \mathrm{PM}_{10}$ ratio of 0.51 was yielded for a study carried out in Cairo between 1998 and 2007 using measurements from fixed monitoring stations (Safar and Labib 2010). The highest $\mathrm{PM}_{2.5} / \mathrm{PM}_{10}$ ratio was recorded in the urban sector $(0.59)$ while the lowest ratio was recorded in the residential sector (0.32) (Zakey et al. 2008). Regionally, the $\mathrm{PM}_{2.5} / \mathrm{PM}_{10}$ ratio was reported as 0.27-0.34 across Beirut, Lebanon and 0.33 for Jeddah, Saudi Arabia (Massoud et al. 2011, Khodeir et al. 2012). Despite these regional ratios being close to the ratios derived by this study, it is important to note that results are not comparable since data collected for the studies have high averaging times (see SI Table S5) while ratios produced by this study are based on short trips in a car microenvironment but show that the ranges are familiar to similar cities in MENA. $\mathrm{PM}_{2.5} / \mathrm{PM}_{10}$ ratios yielded from this study suggest the dominance of coarse particles fractions, owing to the desert-like conditions of Greater Cairo and tyre and brake wear caused by heavy traffic.

\section{$3.5 \quad$ Overview of gaseous pollutant concentrations}

Average $\mathrm{NO}_{2}$ concentrations were $47 \pm 13,38 \pm 10$ and $31 \pm 11 \mu \mathrm{g} / \mathrm{m}^{3}$ for $\mathrm{S} 1, \mathrm{~S} 2$ and $\mathrm{S} 3$, respectively for MP sessions, while EP sessions resulted in $54 \pm 25,28 \pm 18$ and $26 \pm 16 \mu \mathrm{g} / \mathrm{m}^{3}$ for $\mathrm{S} 1, \mathrm{~S} 2$ and $\mathrm{S} 3$, respectively. Like in the case of $\mathrm{PM}, \mathrm{NO}_{2}$ concentrations are highest for $\mathrm{S} 1$ due to highest exposure to the ambient environment and traffic, since $\mathrm{NO}_{2}$ is attributed to road transport emissions (Carslaw et al. 2019). Also, $\mathrm{NO}_{2}$ concentrations are higher for EP sessions than MP sessions. SI Table S7 details mean and standard deviation $\mathrm{NO}_{2}$ concentrations where for $\mathrm{S} 1$; concentrations throughout the zones are within the same range indicating a similar degree of congestion in all high-activity zones. SI Table S7 also details CO data where the average $\mathrm{CO}$ concentrations were $2.8,1.4$ and $4.6 \mathrm{mg} / \mathrm{m}^{3}$ for $\mathrm{S} 1, \mathrm{~S} 2$ and $\mathrm{S} 3$, respectively for 
MP, and 4.5, 1.3 and $7.5 \mathrm{mg} / \mathrm{m}^{3}$ for $\mathrm{S} 1, \mathrm{~S} 2$ and S3, for EP. CO concentrations are higher for S3, which might be due to the incomplete combustion of gasoline during idling.

Data from fixed air quality stations over the past five years in Greater Cairo showed 24-hour averaged $\mathrm{NO}_{2}$ concentrations ranging between 21 and $62 \mu \mathrm{g} / \mathrm{m}^{3}$ while the 8-hour averaged $\mathrm{CO}$ concentrations ranged from 3.3 to $8.5 \mathrm{mg} / \mathrm{m}^{3}$ (Moustafa and Zakey 2018). These concentrations were measured for longer periods and are hence not comparable to the concentrations captured by this study however; it helps to understand national averages to put the results of this study in perspective. Ultimately, $\mathrm{NO}_{2}$ is lowest when the $\mathrm{AC}$ is on, as was the case for $\mathrm{PM}$ however, CO levels were highest for an air-conditioned vehicle. Similar to PM pollution, gaseous pollutant emissions would be mitigated through traffic reduction strategies that include providing public transport options, as well as vehicle enhancement strategies such as retrofitting emission control technologies and prohibiting high age vehicles from roaming the streets through stringent inspection and maintenance programs (Orubu 2004, Shrivastava et al. 2013, United Nations 2013).

\section{Summary, Conclusions and Future Outlook}

We have carried out the first personal exposure field campaign for car commuters in Greater Cairo to determine the underlying factors affecting exposure to PM and gaseous air pollutants. The key conclusions drawn from this study are as follows:

- The choice of car setting affects the levels of PM pollution a user is exposed to where opening windows results higher $\mathrm{PM}_{10}$ concentrations (65\%) and higher $\mathrm{PM}_{2.5}$ average concentrations (48\%) compared to when having windows closed and $\mathrm{AC}$ on.

- Most car users in Greater Cairo need to have windows open because cars are not equipped with $\mathrm{AC}$ and closed window with no ventilation setting is not feasible due to high temperatures hence, car commuters are mostly exposed to average concentrations of $\mathrm{PM}_{10}\left(227 \mu \mathrm{g} / \mathrm{m}^{3}\right)$ and $\mathrm{PM}_{2.5}\left(119 \mu \mathrm{g} / \mathrm{m}^{3}\right)$ while traveling through cross-city routes and $\mathrm{PM}_{10}\left(82 \mu \mathrm{g} / \mathrm{m}^{3}\right)$ and $\mathrm{PM}_{2.5}\left(25 \mu \mathrm{g} / \mathrm{m}^{3}\right)$ while traveling through high-activity zones during peak hours.

- The time of travel also affects PM exposure levels where we have observed higher $\mathrm{PM}_{10}$ (32\%) and $\mathrm{PM}_{2.5}$ (19\%) concentrations during evening peak hours compared to morning peak hours. This trend was proportional to longer average travel times during evening hours. However, traffic in Cairo stands unpredictable and variations are expected. 
- The surrounding environment affects car cabin conditions, especially when windows are open. Geographical zones that are close to desert environment, undergoing construction activities or have unmaintained roads experience up to $64 \%$ higher average $\mathrm{PM}_{10}$ concentrations.

- Cairo commuters typically travel between high-activity zones on a daily basis for work where cross-city routes have shown 1.5 times for $\mathrm{PM}_{10}$ and 3.6 times for $\mathrm{PM}_{2.5}$ the $\mathrm{PM}$ concentrations experienced when travelling within the same zone.

- The dominance of coarse particles $\left(\mathrm{PM}_{2.5}-\mathrm{PM}_{10}\right)$ fraction in Cairo's ambient environment was shown in average $\mathrm{PM}_{2.5} / \mathrm{PM}_{10}$ ratios less than 0.5 , which could be owed to the arid and desert environment of a country such as Egypt.

- Car settings also impacted gaseous pollutant concentrations inside a car where $\mathrm{NO}_{2}$ concentrations were highest during open window conditions as $\mathrm{NO}_{2}$ is a proxy of motor vehicle emissions and is hence affected by traffic congestion. However; CO concentrations were highest for S3, which could be due to the incomplete combustion of gasoline during idling.

Results derived from this study provide knowledge to car commuters that might influence their decision-making and impact traffic demand side management. For example, commuters might start making use of technological alternatives like working and shopping from home, telebanking and organized transport for schools (Abbas et al. 2016) to avoid exposure to transport pollution. Also the identification of hotspots, recommended car settings and different peak hours, allows commuters to make smarter and safer choices. Furthermore, results might feed into government decisions like for example, enforcing a partial driving ban where each citizen must go one day without a car as was implemented in Mexico and parts of South America (Abou-Ali and Thomas 2011). Ultimately, this study has provided a preliminary mapping for PM and gaseous pollutants exposure in the car microenvironment and more studies and campaigns need to be carried out to further investigate hot spots and high exposure routes identified by this study as well as other modes of transport.

\section{Acknowledgements}

This work is carried out under the framework of project- Clean Air Engineering for Cities (CArE-Cities) that is funded by the University of Surrey's Research England funding under the Global Challenge Research Fund (GCRF) programme. The earlier Research England GCRF funding that was awarded to the Reducing the Impact of Health and Climate Emissions 
in Megacity Cairo (RETINA) project in 2017-18, has allowed this work to be implemented through the rental of needed equipment. We thank El-Nada Scientific Firm and the capable technical team who supported the researchers in data collection.

\section{References}

Abbas, K., Alsalem, A., Belwal, R., Delatte, A., Mosa, A.I., Nakkash, T., Ramadan, A., Webb, S., and Vautier, P., 2016. MENA Center for Transport Excellence Jounral. International Association of Public Transport.

Abhijith, K.V. and Kumar, P., 2019. Field investigations for evaluating green infrastructure effects on air quality in open-road conditions. Atmospheric Environment, 201, 132-147.

Abou-Ali, H. and Thomas, A., 2011. Regulating Traffic to Reduce Air Pollution in Greater Cairo, Egypt. Economic Research Forum (ERF), Working Paper No. 664. Available at: www.erf.org.eg, last accessed: 31 January 2018.

Abu-Allaban, M., Lowenthal, D.H., Gertler, A.W., and Labib, M., 2007. Sources of PM10 and $\mathrm{PM}_{2.5}$ in Cairo's ambient air. Environmental Monitoring and Assessment, 133 (1-3), 417425.

Ahmed, S., Adnan, M., Janssens, D., and Wets, G., 2020. A route to school informational intervention for air pollution exposure reduction. Sustainable Cities and Society, 53, 101965.

Al Katheeri, E., Al Jallad, F., and Al Omar, M., 2012. Assessment of Gaseous and Particulate Pollutants in the Ambient Air in Al Mirfa City, United Arab Emirates. Journal of Environmental Protection, 03 (07), 640-647.

Alnawaiseh, N.A., Hashim, J.H., and Md Isa, Z., 2015. Relationship Between Vehicle Count and Particulate Air Pollution in Amman, Jordan. Asia Pacific Journal of Public Health, 27 (2), NP1742-NP1751.

Amato, F., Cassee, F.R., Denier van der Gon, H.A.C., Gehrig, R., Gustafsson, M., Hafner, W., Harrison, R.M., Jozwicka, M., Kelly, F.J., Moreno, T., Prevot, A.S.H., Schaap, M., Sunyer, J., and Querol, X., 2014. Urban air quality: The challenge of traffic non-exhaust emissions. Journal of Hazardous Materials, 275, 31-36.

Amato, F., Querol, X., Alastuey, A., Pandolfi, M., Moreno, T., Gracia, J., and Rodriguez, P., 2009. Evaluating urban $\mathrm{PM}_{10}$ pollution benefit induced by street cleaning activities. Atmospheric Environment, 43 (29), 4472-4480. 
Apparicio, P., Gelb, J., Carrier, M., Mathieu, M.-È., and Kingham, S., 2018. Exposure to noise and air pollution by mode of transportation during rush hours in Montreal. Journal of Transport Geography, 70, 182-192.

Brown, K.W., Bouhamra, W., Lamoureux, D.P., Evans, J.S., and Koutrakis, P., 2008. Characterization of Particulate Matter for Three Sites in Kuwait. Journal of the Air \& Waste Management Association, 58 (8), 994-1003.

CAPMAS, 2017. Inventory of Licensed Vehicles for 2016. Cairo, Egypt: Central Agency for Public Mobilization and Statistics, No. 71-21315-2016. Available at: https://www.capmas.gov.eg, last accessed: 7 September 2018.

Cepeda, M., Schoufour, J., Freak-Poli, R., Koolhaas, C.M., Dhana, K., Bramer, W.M., and Franco, O.H., 2017. Levels of ambient air pollution according to mode of transport: a systematic review. The Lancet Public Health, 2 (1), e23-e34.

Chaney, R.A., Sloan, C.D., Cooper, V.C., Robinson, D.R., Hendrickson, N.R., McCord, T.A., and Johnston, J.D., 2017. Personal exposure to fine particulate air pollution while commuting: An examination of six transport modes on an urban arterial roadway. PLOS ONE, 12 (11), e0188053.

Chapman, L., 2007. Transport and climate change: a review. Journal of Transport Geography, 15 (5), 354-367.

Chen, Y., Schleicher, N., Chen, Y., Chai, F., and Norra, S., 2014. The influence of governmental mitigation measures on contamination characteristics of $\mathrm{PM}_{2.5}$ in Beijing. Science of The Total Environment, 490, 647-658.

Duquennois, A.N. and Newman, P., 2009. Linking the Green and Brown Agendas: A Case Study on Cairo, Egypt. UN Habitat, Global Report on Human Settlements 2009. Available at: http://www.unhabitat.org/grhs/2009, last accessed: 9 December 2018.

El-Dorghamy, A., Allam, H., Al-Abyad, A., and Gasnier, M., 2015. Fuel Economy and $\mathrm{CO}_{2}$ Emissions of Light-Duty Vehicles in Egypt. Centre for Environment and Development in the Arab Region and Europe (CEDARE). Available at: http://web.cedare.org/, last accessed: 17 February 2018.

El-Kadi, A. W., 2013. Suggested Solutions for Traffic Congestion in Greater Cairo. Journal of Sustainable Development, 6 (11).

El-Mansy, A.H.A.E.-L., Heikal, A.Z.E.S., and Abo Taleb, A.S., 2013. Integration Of GPS And GIS to Study Traffic Congestion on Cairo Road Network to Minimize the Harmful Environmental Effects - Case Study (Autostrad Road). In Partial Fulfillment of the Requirement for the Master Degree. Ain Shams University, Cairo Egypt. 
Embiale, A., Zewge, F., Chandravanshi, B.S., and Sahle-Demessie, E., 2019. Commuter exposure to particulate matters and total volatile organic compounds at roadsides in Addis Ababa, Ethiopia. International Journal of Environmental Science and Technology, $16(8), 4761-4774$.

Grigoratos, T. and Martini, G., 2014. Non-exhaust traffic related emissions. Brake and tyre wear PM - Literature Review. European Union: European Commission Joint Research Centre Institute of Energy and Transport. Available at: https://ec.europa.eu/jrc/, last accessed: 12 January 2020.

Hama, S.M.L., Kumar, P., Harrison, R.M., Bloss, W.J., Khare, M., Mishra, S., Namdeo, A., Sokhi, R., Goodman, P., and Sharma, C., 2020. Four-year assessment of ambient particulate matter and trace gases in the Delhi-NCR region of India. Sustainable Cities and Society, 54, 102003.

Harrison, R.M., Jones, A.M., Gietl, J., Yin, J., and Green, D.C., 2012. Estimation of the Contributions of Brake Dust, Tire Wear, and Resuspension to Nonexhaust Traffic Particles Derived from Atmospheric Measurements. Environmental Science \& Technology, 46 (12), 6523-6529.

Hassan, H.A., Tsiouri, V.K., and Konstantinos, K.E., 2015. Developing Emission Factors Of Fugitive Particulate Matter Emissions For Construction Sites In The Middle East Area. International Journal of Environmental and Ecological Engineering, 9 (2), 50-54.

Hassanien, M.A. and Abdel-Latif, N.M., 2008. Polycyclic aromatic hydrocarbons in road dust over Greater Cairo, Egypt. Journal of Hazardous Materials, 151 (1), 247-254.

Huzayyin, A.S. and Salem, H., 2013. Analysis of thirty years evolution of urban growth, transport demand and supply, energy consumption, greenhouse and pollutants emissions in Greater Cairo. Research in Transportation Economics, 40 (1), 104-115.

Huzayyin, A.S., Salem, H., El Sherbini, E., Anwer, M., and Omar, S., 2009. Urban Mobility in Greater Cairo; Trends and Prospects. Cairo University: Development Research and Technological Planning Center. Available at: http://www.drtpc.org/web/en/, last accessed: 12 September 2018.

Khodeir, M., Shamy, M., Alghamdi, M., Zhong, M., Sun, H., Costa, M., Chen, L.-C., and Maciejczyk, P., 2012. Source apportionment and elemental composition of $\mathrm{PM}_{2.5}$ and $\mathrm{PM}_{10}$ in Jeddah City, Saudi Arabia. Atmospheric Pollution Research, 3 (3), 331-340.

Kole, P.J., Löhr, A.J., Van Belleghem, F., and Ragas, A., 2017. Wear and Tear of Tyres: A Stealthy Source of Microplastics in the Environment. International Journal of Environmental Research and Public Health, 14 (10), 1265. 
Kouyoumdjian, H. and Saliba, N.A., 2006. Mass concentration and ion composition of coarse and fine particles in an urban area in Beirut: effect of calcium carbonate on the absorption of nitric and sulfuric acids and the depletion of chloride. Atmospheric Chemistry and Physics, 6 (7), 1865-1877.

Krzyzanowski, M., Kuna-Dibbert, B., and Schneider, J., 2005. Health effects of transportrelated air pollution. Copenhagen, Denmark: World Health Organization, No. ISBN 92 8901373 7. Available at: http://www.euro.who.int, last accessed: 13 September 2018.

Kumar, P., Adelodun, A.A., Khan, M.F., Krisnawati, H., and Garcia-Menendez, F., 2020. Towards an improved understanding of greenhouse gas emissions and fluxes in tropical peatlands of Southeast Asia. Sustainable Cities and Society, 53, 101881.

Kumar, P., Druckman, A., Gallagher, J., Gatersleben, B., Allison, S., Eisenman, T.S., Hoang, U., Hama, S., Tiwari, A., Sharma, A., Abhijith, KV, Adlakha, D., McNabola, A., AstellBurt, T., Feng, X., Skeldon, A.C., de Lusignan, S., Morawska, L., 2019. The Nexus between Air Pollution, Green Infrastructure and Human Health. Environment International 133,105181.

Kumar, P., Morawska, L., Martani, C., Biskos, G., Neophytou, M., Di Sabatino, S., Bell, M., Norford, L., and Britter, R., 2015. The rise of low-cost sensing for managing air pollution in cities. Environment International, 75, 199-205.

Kumar, P., Gulia, S., Harrison, R.M., and Khare, M., 2017. The influence of odd-even car trial on fine and coarse particles in Delhi. Environmental Pollution, 225, 20-30.

Kumar, P., Patton, A.P., Durant, J.L., and Frey, H.C., 2018a. A review of factors impacting exposure to $\mathrm{PM}_{2.5}$, ultrafine particles and black carbon in Asian transport microenvironments. Atmospheric Environment, 187, 301-316.

Kumar, P., Rivas, I., Singh, A.P., Ganesh, V.J., Ananya, M., Frey, H.F, 2018b. Dynamics of coarse and fine particles exposure in transport microenvironments. npj Climate and Atmospheric Science, 1, 11, doi: 10.1038/s41612-018-0023-y

Lin, C., Gillespie, J., Schuder, M.D., Duberstein, W., Beverland, I.J., and Heal, M.R., 2015. Evaluation and calibration of Aeroqual series 500 portable gas sensors for accurate measurement of ambient ozone and nitrogen dioxide. Atmospheric Environment, 100, $111-116$.

Li, Y., Gibson, J.M., Jat, P., Puggioni, G., Hasan, M., West, J.J., Vizuete, W., Sexton, K., and Serre, M., 2010. Burden of disease attributed to anthropogenic air pollution in the United Arab Emirates: Estimates based on observed air quality data. Science of The Total Environment, 408 (23), 5784-5793. 
Lowenthal, D.H., Gertler, A.W., and Labib, M.W., 2014. Particulate matter source apportionment in Cairo: recent measurements and comparison with previous studies. International Journal of Environmental Science and Technology, 11 (3), 657-670.

Luangprasert, M., Vasithamrong, C., Pongratananukul, S., Chantranuwathana, S., Pumrin, S., and De Silva, I.P.D., 2017. In-vehicle carbon dioxide concentration in commuting cars in Bangkok, Thailand. Journal of the Air \& Waste Management Association, 67 (5), 623633.

Mahajan, S., Kumar, P., Pinto, J.A., Riccetti, A., Schaaf, K., Camprodon, G., Smári, V., Passani, A., and Forino, G., 2020. A citizen science approach for enhancing public understanding of air pollution. Sustainable Cities and Society, 52, 101800.

Martins, N.R. and Carrilho da Graça, G., 2018. Impact of $\mathrm{PM}_{2.5}$ in indoor urban environments: A review. Sustainable Cities and Society, 42, 259-275.

Massoud, R., Shihadeh, A.., Roumié, M., Youness, M., Gerard, J., Saliba, N., Zaarour, R., Abboud, M., Farah, W., and Saliba, N.A., 2011. Intraurban variability of PM10 and PM2.5 in an Eastern Mediterranean city. Atmospheric Research, 101 (4), 893-901.

McKercher, G.R., Salmond, J.A., and Vanos, J.K., 2017. Characteristics and applications of small, portable gaseous air pollution monitors. Environmental Pollution, 223, 102-110.

Monks, P., Allan, J., Carruthers, D., Carslaw, D., and Fuller, G., 2019. Non-Exhaust Emissions from Road Traffic. Department for Environment, Food and Rural Affairs; Scottish Government; Welsh Government; and Department of the Environment in Northern Ireland, Air Quality Expert Group, 8-75. Available at: http://uk-air.defra.gov.uk, last accessed: 12 January 2020.

Moustafa, A.N. and Zakey, A.S., 2018. Analysis of the Surface Air Quality Measurements in the Greater Cairo (Egypt) Metropolitan. Global Journal of Advanced Research, 5 (6), 207-214.

Müller, D., Klingelhöfer, D., Uibel, S., and Groneberg, D.A., 2011. Car indoor air pollution analysis of potential sources. Journal of Occupational Medicine and Toxicology, 6 (1), 33.

Nabi, G.R.B. and Halek, F., 2007. Aerosol Size Segregated of Tehran's Atmosphere in Iran. Int. J. Environ. Res., 1 (1), 58-65.

Nagendra, S.M.S., Yasa, P.R., Mv, N., Khadirnaikar, S., and Pooja Rani, 2019. Mobile monitoring of air pollution using low cost sensors to visualize spatio-temporal variation of pollutants at urban hotspots. Sustainable Cities and Society, 44, 520-535. 
Nasser, Z., Salameh, P., Nasser, W., Abou Abbas, L., Elias, E., and Leveque, A., 2015. Outdoor particulate matter (PM) and associated cardiovascular diseases in the Middle East. International Journal of Occupational Medicine and Environmental Health, 28 (4), 641661.

Okokon, E.O., Taimisto, P., Turunen, A.W., Amoda, O.A., Fasasi, A.E., Adeyemi, L.G., Juutilainen, J., and Lanki, T., 2018. Particulate air pollution and noise: Assessing commuter exposure in Africa's most populous city. Journal of Transport \& Health, 9, $150-160$.

Ortolani, C. and Vitale, M., 2016. The importance of local scale for assessing, monitoring and predicting of air quality in urban areas. Sustainable Cities and Society, 26, 150-160.

Orubu, C.O., 2004. Using Transportation Control Measures and Economic Instruments to Reduce Air Pollution Due to Automobile Emissions. Journal of Social Sciences, 8 (3), $227-236$.

Ottosen, T.-B. and Kumar, P., 2020. The influence of the vegetation cycle on the mitigation of air pollution by a deciduous roadside hedge. Sustainable Cities and Society, 53, 101919.

Parry, I.W.H. and Timilsina, G.R., 2015. Demand-Side Instruments to Reduce Road Transportation Externalities in the Greater Cairo Metropolitan Area. International Journal of Sustainable Transportation, 9 (3), 203-216.

Petkova, E.P., Jack, D.W., Volavka-Close, N.H., and Kinney, P.L., 2013. Particulate matter pollution in African cities. Air Quality, Atmosphere \& Health, 6 (3), 603-614.

Pilla, F. and Broderick, B., 2015. A GIS model for personal exposure to $\mathrm{PM}_{10}$ for Dublin commuters. Sustainable Cities and Society, 15, 1-10.

Qiu, Z., Xu, X., Song, J., Luo, Y., Zhao, R., Zhou, B.X.W., Li, X., and Hao, Y., 2017. Pedestrian exposure to traffic PM on different types of urban roads: A case study of Xi'an, China. Sustainable Cities and Society, 32, 475-485.

Requia, W.J., Adams, M.D., Arain, A., Papatheodorou, S., Koutrakis, P., and Mahmoud, M., 2018. Global Association of Air Pollution and Cardiorespiratory Diseases: A Systematic Review, Meta-Analysis, and Investigation of Modifier Variables. American Journal of Public Health, 108 (S2), S123-S130.

Saade, L., 2016. Air pollution deaths cost economies in Middle East and North Africa more than $\$ 9$ billion. States News Service Newswire, 8 Sep. Available at: https://www.worldbank.org/, last accessed: 21 October 2016. 
Safar, Z.S. and Labib, M.W., 2010. Assessment of particulate matter and lead levels in the Greater Cairo area for the period 1998-2007. Journal of Advanced Research, 1 (1), 5363.

Shahsavani, A., Naddafi, K., Jafarzade Haghighifard, N., Mesdaghinia, A., Yunesian, M., Nabizadeh, R., Arahami, M., Sowlat, M.H., Yarahmadi, M., Saki, H., Alimohamadi, M., Nazmara, S., Motevalian, S.A., and Goudarzi, G., 2012. The evaluation of $\mathrm{PM}_{10}, \mathrm{PM}_{2.5}$, and $\mathrm{PM}_{1}$ concentrations during the Middle Eastern Dust (MED) events in Ahvaz, Iran, from April through September 2010. Journal of Arid Environments, 77, 72-83.

Shrivastava, R.K., Neeta, S., and Geeta, G., 2013. Air Pollution due to Road Transportation in India: A Review on Assessment and Reduction Strategies. Journal of Environmental Research And Development, 8 (1), 69-77.

Shukla, K., Kumar, P., Mann, G.S., and Khare, M., 2020. Mapping spatial distribution of particulate matter using Kriging and Inverse Distance Weighting at supersites of megacity Delhi. Sustainable Cities and Society, 54, 101997.

Soliman, M.E., Bassily, R.E., Khedr, S.A., Saudy, M.M., Fahmy, E.H., and Khalil, O.I., 2016. Solution Model for Urban Traffic Congestion: Egyptian Case Study. London: Resilient Infrastructure, No. TRA-954-1.

Sommer, F., Dietze, V., Baum, A., Sauer, J., Gilge, S., Maschowski, C., and Gieré, R., 2018. Tire Abrasion as a Major Source of Microplastics in the Environment. Aerosol and Air Quality Research, 18 (8), 2014-2028.

Tsiouri, V., Kakosimos, K.E., and Kumar, P., 2015. Concentrations, sources and exposure risks associated with particulate matter in the Middle East Area-a review. Air Quality, Atmosphere \& Health, 8 (1), 67-80.

United Nations, 2013. Strategies and Policies for Air Pollution Abatement. Switzerland: United Nations Economic Commission for Europe, No. ECE/EB.AIR/123. Available at: http://www.unece.org, last accessed: 17 January 2020.

United Nations, 2018. The World's Cities in 2018 Data Booklet. Department of Economic and Social Affairs, Population Divi- sion, No. ST/ESA/ SER.A/417. Available at: https://www.un.org/en/, last accessed: 6 May 2019.

Waked, A. and Afif, C., 2012. Emissions of air pollutants from road transport in Lebanon and other countries in the Middle East region. Atmospheric Environment, 61, 446-452.

WHO, 2003. Health Aspects of Air Pollution with Particulate Matter, Ozone and Nitrogen Dioxide. Bonn, Germany: World Health Organization, Report on a WHO Working 
Group No. EUR/03/5042688. Available at: http://www.euro.who.int/, last accessed: 13 September 2018.

Viecco, M., Vera, S., Jorquera, H., Bustamante, W., Gironás, J., Dobbs, C., and Leiva, E., 2018. Potential of Particle Matter Dry Deposition on Green Roofs and Living Walls Vegetation for Mitigating Urban Atmospheric Pollution in Semiarid Climates. Sustainability, 10 (7), 2431.

Zakey, A.S., Abdel-Wahab, M.M., Petterson, J.B.C., Gatari, M.J., and Halliquist, M., 2008. Seasonal and spatial variation of atmospheric particulate matter in a developing megacity, the Greater Cairo, Egypt. Atmósfera, 21 (2), 171-189. 


\section{List of Tables}

Table 1: Summary of $\mathrm{PM}_{10}$ and $\mathrm{PM}_{2.5}$ pollution field studies carried out in the MENA.

\begin{tabular}{|c|c|c|c|}
\hline Location & Study Focus & Major Findings & $\begin{array}{l}\text { Author } \\
\text { (year) }\end{array}$ \\
\hline $\begin{array}{l}\text { Cairo, } \\
\text { Egypt }\end{array}$ & $\begin{array}{l}\text { Air quality } \\
\text { measurements }\end{array}$ & $\begin{array}{l}\text { Data collected from fixed stations showed that } \\
\text { emission levels considerably exceed national } \\
\text { standards. }\end{array}$ & $\begin{array}{l}\text { Moustafa } \\
\text { and Zakey } \\
(2018) \\
\end{array}$ \\
\hline $\begin{array}{l}\text { Amman, } \\
\text { Jordan }\end{array}$ & $\begin{array}{l}\text { Vehicle count } \\
\text { versus air } \\
\text { pollution }\end{array}$ & $\begin{array}{l}\text { TSP and } \mathrm{PM}_{10} \text { are significantly correlated with } \\
\text { traffic count even after controlling temperature, } \\
\text { humidity and wind. }\end{array}$ & $\begin{array}{l}\text { Alnawaiseh } \\
\text { et al. } \\
(2015)\end{array}$ \\
\hline $\begin{array}{l}\text { Doha, } \\
\text { Qatar }\end{array}$ & $\begin{array}{l}\text { Emission } \\
\text { factors for } \\
\text { construction } \\
\text { sites }\end{array}$ & $\begin{array}{l}\text { PM USEPA emission factors were determined } \\
\text { and new emission rates were developed for the } \\
\text { Middle East. }\end{array}$ & $\begin{array}{l}\text { Hassan et } \\
\text { al. (2015) }\end{array}$ \\
\hline $\begin{array}{l}\text { Middle } \\
\text { East }\end{array}$ & $\begin{array}{l}\text { Cardiovascula } \\
\text { r diseases by } \\
\text { PM }\end{array}$ & $\begin{array}{l}-\mathrm{PM}_{2.5} \text { and } \mathrm{PM}_{10} \text { annual averages of } 85 \text { and } 170 \\
\mu \mathrm{g} / \mathrm{m}^{3} \text {. } \\
\text {-Study limited by the lack of air monitoring } \\
\text { stations. }\end{array}$ & $\begin{array}{l}\text { Nasser et } \\
\text { al. }(2015)\end{array}$ \\
\hline $\begin{array}{l}\text { Middle } \\
\text { East }\end{array}$ & $\begin{array}{l}\text { PM sources } \\
\text { and impacts }\end{array}$ & $\begin{array}{l}\text {-A need for inventories to quantify source } \\
\text { contributions. } \\
\text {-Studies are limited in terms of location and } \\
\text { duration. }\end{array}$ & $\begin{array}{l}\text { Tsiouri et } \\
\text { al. }(2015)\end{array}$ \\
\hline $\begin{array}{l}\text { Cairo, } \\
\text { Egypt }\end{array}$ & $\begin{array}{l}\text { PM } \\
\text { monitoring } \\
\text { and source } \\
\text { apportionment }\end{array}$ & $\begin{array}{l}\text {-The largest contributor to } \mathrm{PM}_{2.5} \text { was motor } \\
\text { vehicles. } \\
\text {-Contributors to } \mathrm{PM}_{10} \text { included re-suspended } \\
\text { dust, mobile source emissions and open burning. } \\
\text { - } \mathrm{PM}_{10} \text { standard exceeded } 91 \text { and } 96 \% \text { of the time. }\end{array}$ & $\begin{array}{l}\text { Lowenthal } \\
\text { et al. } \\
\text { (2014) }\end{array}$ \\
\hline $\begin{array}{l}\text { North } \\
\text { African } \\
\text { Cities }\end{array}$ & $\begin{array}{l}\text { PM } \\
\text { monitoring } \\
\text { campaigns }\end{array}$ & $\begin{array}{l}\text {-In Algeria, } \mathrm{PM}_{10} \text { was } 38 \text { to } 129 \mu \mathrm{g} / \mathrm{m}^{3} \text { in } 2002 \text { - } \\
2003 \text {. } \\
\text {-In Tunisia, } \mathrm{PM}_{10} \text { of } 66 \mu \mathrm{g} / \mathrm{m}^{3} \text { was measured in } \\
\text { 1996-1997. } \\
\text {-In Morocco, } \mathrm{PM}_{10} \text { of } 81 \mu \mathrm{g} / \mathrm{m}^{3} \text { was measured in } \\
\text { 2007. }\end{array}$ & $\begin{array}{l}\text { Petkova et } \\
\text { al. (2013) }\end{array}$ \\
\hline $\begin{array}{l}\text { Al-Mirfa, } \\
\text { UAE }\end{array}$ & $\begin{array}{l}\text { Assessment of } \\
\text { gaseous and } \\
\text { PM pollutants }\end{array}$ & $\begin{array}{l}-\mathrm{PM}_{10} \text { varies in the range of } 4-1426 \mu \mathrm{g} / \mathrm{m}^{3} \text {. } \\
\text {-Concentrations exceeded the limit by } 62-88 \\
\text { times. }\end{array}$ & $\begin{array}{l}\text { Al Katheeri } \\
\text { et al. } \\
(2012)\end{array}$ \\
\hline $\begin{array}{l}\text { Jeddah, } \\
\text { KSA }\end{array}$ & $\begin{array}{l}\text { Composition } \\
\text { of PM }\end{array}$ & $\begin{array}{l}\text { The overall mean mass concentration was } 28 \pm 25 \\
\mu \mathrm{g} / \mathrm{m}^{3} \text { for } \mathrm{PM}_{2.5} \text { and } 87 \pm 47 \mu \mathrm{g} / \mathrm{m}^{3} \text { for } \mathrm{PM}_{10} \text {. }\end{array}$ & $\begin{array}{l}\text { Khodeir et } \\
\text { al. (2012) }\end{array}$ \\
\hline $\begin{array}{l}\text { Ahvaz, } \\
\text { Iran }\end{array}$ & $\begin{array}{l}\text { PM during } \\
\text { dust events }\end{array}$ & $\begin{array}{l}\text {-Overall mean values of } 319 \pm 407,69 \pm 83 \text {, and } \\
37 \pm 34 \mu \mathrm{g} / \mathrm{m}^{3} \text { were obtained for } \mathrm{PM}_{10}, \mathrm{PM}_{2.5} \text {, and } \\
\mathrm{PM}_{1}, \text { respectively. }\end{array}$ & $\begin{array}{l}\text { Shahsavani } \\
\text { et al. } \\
(2012)\end{array}$ \\
\hline $\begin{array}{l}\text { Beirut, } \\
\text { Lebanon }\end{array}$ & $\begin{array}{l}\text { Urban } \\
\text { variability of } \\
\mathrm{PM}_{10} \text { and } \\
\mathrm{PM}_{2.5}\end{array}$ & $\begin{array}{l}\text {-Mass concentrations varied between } 20 \text { and } 521 \\
\mu \mathrm{g} / \mathrm{m}^{3} \text { for } \mathrm{PM}_{10} \text { and between } 8 \text { and } 72 \mu \mathrm{g} / \mathrm{m}^{3} \text { for } \\
\mathrm{PM}_{2.5} \text {. }\end{array}$ & $\begin{array}{l}\text { Massoud et } \\
\text { al. (2011) }\end{array}$ \\
\hline
\end{tabular}




\begin{tabular}{|c|c|c|c|}
\hline Location & Study Focus & Major Findings & $\begin{array}{l}\text { Author } \\
\text { (year) }\end{array}$ \\
\hline UAE & $\begin{array}{l}\text { Diseases } \\
\text { caused by air } \\
\text { pollution }\end{array}$ & $\begin{array}{l}\text { Approximately } 545 \text { excess deaths in the UAE in } \\
2007 \text { are attributable to PM in ambient air ( } 7 \% \text { of } \\
\text { the total deaths). }\end{array}$ & $\begin{array}{l}\text { Li et al. } \\
(2010)\end{array}$ \\
\hline $\begin{array}{l}\text { Cairo, } \\
\text { Egypt }\end{array}$ & $\begin{array}{l}\text { Assessment of } \\
\text { PM 1998- } \\
2007\end{array}$ & $\begin{array}{l}\text { It can be concluded that the } \mathrm{PM}_{10} 24 \mathrm{~h} \text { daily } \\
\text { average is fluctuating around the average value } \\
\text { stated by the law. }\end{array}$ & $\begin{array}{l}\text { Safar and } \\
\text { Labib } \\
\text { (2010) }\end{array}$ \\
\hline Kuwait & $\begin{array}{l}\text { Characterizati } \\
\text { on of PM }\end{array}$ & $\begin{array}{l}-\mathrm{PM}_{10} \text { ranged from } 66 \text { to } 93 \mu \square \mathrm{g} / \mathrm{m}^{3} \text { across the } \\
\text { three sites. } \\
-\mathrm{PM}_{2.5} \text { concentrations varied from } 38 \text { and } 37 \\
\mu \mathrm{g} / \mathrm{m}^{3} \text {. }\end{array}$ & $\begin{array}{l}\text { Brown et } \\
\text { al. }(2008)\end{array}$ \\
\hline $\begin{array}{l}\text { Cairo, } \\
\text { Egypt }\end{array}$ & $\begin{array}{l}\text { Variation of } \\
\text { atmospheric } \\
\text { PM }\end{array}$ & $\begin{array}{l}\text {-High PM in during spring due to dust storm } \\
\text { events. } \\
\text {-Increase in PM levels in fall due to burning of } \\
\text { rice straw. }\end{array}$ & $\begin{array}{l}\text { Zakey et al. } \\
(2008)\end{array}$ \\
\hline $\begin{array}{l}\text { Cairo, } \\
\text { Egypt }\end{array}$ & $\begin{array}{l}\text { Sources of } \\
\mathrm{PM}_{10} \text { and } \\
\mathrm{PM}_{2.5}\end{array}$ & $\begin{array}{l}\text { - } \mathrm{PM}_{10} \text { : geological, mobile sources and open } \\
\text { burning } \\
\text { - } \mathrm{PM}_{2.5} \text { : mobile source emissions and open } \\
\text { burning }\end{array}$ & $\begin{array}{l}\text { Abu- } \\
\text { Allaban et } \\
\text { al. (2007) }\end{array}$ \\
\hline $\begin{array}{l}\text { Tehran, } \\
\text { Iran }\end{array}$ & $\begin{array}{l}\text { Aerosol size } \\
\text { segregation }\end{array}$ & $\begin{array}{l}\text {-Annual average exceeds the standard of } 50 \\
\mu \mathrm{g} / \mathrm{m}^{3} \text {. } \\
-\mathrm{PM}_{2.5} \text { in roadside areas exceeds daily average of } \\
65 \mu \mathrm{g} / \mathrm{m}^{3} \text {. }\end{array}$ & $\begin{array}{l}\text { Nabi and } \\
\text { Halek } \\
(2007)\end{array}$ \\
\hline $\begin{array}{l}\text { Beirut, } \\
\text { Lebanon }\end{array}$ & $\begin{array}{l}\mathrm{PM} \\
\text { concentration } \\
\text { and } \\
\text { composition }\end{array}$ & $\begin{array}{l}\text {-Low PM in rainy season, high levels during sand } \\
\text { storms. } \\
\text {-Annual averages of } \mathrm{PM}_{10}, \mathrm{PM}_{10-2.5} \text { and } \mathrm{PM}_{2.5} \\
\text { concentrations were } 84 \pm 27,53 \pm 20 \text { and } 31 \pm 9 \\
\mu \mathrm{g} / \mathrm{m}^{3} \text {. }\end{array}$ & $\begin{array}{l}\text { Kouyoumdj } \\
\text { ian and } \\
\text { Saliba } \\
(2006)\end{array}$ \\
\hline
\end{tabular}


Table 2. Summary of car exposure study. For each zone/route, the street names and areas that were travelled are listed along with the length of the chosen route in kilometres. The average time taken in minutes for each zone/route is listed along with corresponding dimensionless standard deviation numbers. The total time taken in minutes and the number of trips (between brackets) conducted is defined for each studied parameter; $\mathrm{PM}_{10}$ and $\mathrm{PM}_{2.5}$ (PM data collected in same trip), $\mathrm{NO}_{2}$ and $\mathrm{CO}$.

\begin{tabular}{|c|c|c|c|c|c|c|c|}
\hline \multirow[t]{2}{*}{ Zone/Route } & \multicolumn{2}{|c|}{ Street/Area Names } & \multirow[t]{2}{*}{$\begin{array}{c}\text { Route } \\
\text { Length } \\
(\mathbf{k m})\end{array}$} & \multirow[t]{2}{*}{$\begin{array}{c}\text { Average } \\
\text { time } \pm \\
\text { SD }(\min )\end{array}$} & \multicolumn{3}{|c|}{$\begin{array}{l}\text { Total time for collected } \\
\text { data in minutes (\# of } \\
\text { trips)* }\end{array}$} \\
\hline & $\begin{array}{l}\text { Main } \\
\text { street }\end{array}$ & Residential & & & $\begin{array}{l}\text { PM10 } \\
\text { and } \\
\text { PM}_{2.5}\end{array}$ & $\mathrm{NO}_{2}$ & $\mathrm{CO}$ \\
\hline Z1: Heliopolis & $\begin{array}{l}\text { El- } \\
\text { Nozha } \\
\text { and Al- } \\
\text { Thawra }\end{array}$ & $\begin{array}{l}\text { El-Korba } \\
\text { villas }\end{array}$ & 12 & $17 \pm 3$ & $138(9)$ & $\begin{array}{l}146 \\
(9)\end{array}$ & $\begin{array}{l}151 \\
(9)\end{array}$ \\
\hline Z2: Al-Maadi & $\begin{array}{l}\text { Al-Nasr } \\
\text { and Al- } \\
\text { Lasilki }\end{array}$ & $\begin{array}{l}\text { Degla and } \\
\text { CAC } \\
\text { school area } \\
\end{array}$ & 6 & $18 \pm 3$ & $179(9)$ & $98(6)$ & $\begin{array}{l}103 \\
(9)\end{array}$ \\
\hline $\begin{array}{l}\text { Z3: New } \\
\text { Cairo } \\
\end{array}$ & $\begin{array}{l}\text { South } \\
\text { Teseen } \\
\end{array}$ & $\begin{array}{l}\text { Al-Narges } \\
\text { area }\end{array}$ & 12 & $21 \pm 4$ & $192(9)$ & $\begin{array}{l}114 \\
(6) \\
\end{array}$ & $\begin{array}{l}157 \\
(6) \\
\end{array}$ \\
\hline $\begin{array}{l}\text { Z4: } \\
\text { Downtown }\end{array}$ & $\begin{array}{l}\text { Tahrir } \\
\text { Square } \\
\text { and Qasr } \\
\text { El-Nile }\end{array}$ & $\begin{array}{l}\text { Bab Al- } \\
\text { Louq }\end{array}$ & 3 & $16 \pm 2$ & $96(6)$ & $97(6)$ & $93(6)$ \\
\hline $\begin{array}{l}\text { Z5: El- } \\
\text { Mohandesseen }\end{array}$ & $\begin{array}{l}\text { Al- } \\
\text { Dokki }\end{array}$ & $\begin{array}{l}\text { Nadi El- } \\
\text { Seed area }\end{array}$ & 6 & $14 \pm 1$ & $85(6)$ & $83(6)$ & $86(6)$ \\
\hline $\begin{array}{l}\text { Z6: } 6^{\text {th }} \text { of } \\
\text { October City }\end{array}$ & $\begin{array}{l}26^{\text {th }} \text { of } \\
\text { July } \\
\text { Corridor }\end{array}$ & Al-Bostan & 12 & $17 \pm 3$ & $114(6)$ & $98(6)$ & $92(6)$ \\
\hline $\begin{array}{l}\text { Cross-city } \\
\text { route }\end{array}$ & \multicolumn{2}{|c|}{$\begin{array}{l}\text { Salah Salem st, } 6^{\text {th }} \text { of } \\
\text { October Bridge, } 26^{\text {th }} \text { of } \\
\text { July Corridor and } \\
\text { segments of the Ring } \\
\text { Road }\end{array}$} & 115 & $166 \pm 26$ & $995(6)$ & N/A & N/A \\
\hline Background & \multicolumn{2}{|c|}{ Outskirts of Cairo } & N/A & $40 \pm 2$ & $\begin{array}{l}121 \\
(12)\end{array}$ & $\begin{array}{l}124 \\
(12)\end{array}$ & $\begin{array}{l}122 \\
(12)\end{array}$ \\
\hline Roadside & \multicolumn{2}{|c|}{ El-Merghani St. } & N/A & $21 \pm 1$ & $62(6)$ & $63(6)$ & $63(6)$ \\
\hline
\end{tabular}

* Weekend runs added to Z1, Z2 and Z3 data. 
Table 3. Particulate matter measurements results summary where $n$ : number of data points and mean in $\mu \mathrm{g} / \mathrm{m}^{3}$ (standard deviation in dimensionless units). $\mathrm{PM}_{2.5} / \mathrm{PM}_{10}$ lists the ratio for each session.

\begin{tabular}{|c|c|c|c|c|c|c|c|c|c|c|c|c|c|}
\hline & \multicolumn{4}{|c|}{ S1: Open Window } & \multicolumn{4}{|c|}{ S2: Closed Window } & \multicolumn{4}{|c|}{ S3: AC On } \\
\hline & & $\mathbf{n}$ & PM10 & $\mathbf{P M}_{2.5}$ & $\begin{array}{l}\mathbf{P M}_{2.5} / \\
\text { PM10 }_{10} \\
\end{array}$ & $\mathbf{n}$ & $\mathbf{P M}_{10}$ & $\mathbf{P M}_{2.5}$ & $\begin{array}{l}\mathbf{P M}_{2.5} / \\
\text { PM10 }_{10} \\
\end{array}$ & $\mathrm{n}$ & $\mathbf{P M}_{10}$ & $\mathbf{P M}_{2.5}$ & $\begin{array}{l}P_{2.5} / \\
P_{10} \\
\end{array}$ \\
\hline \multirow{6}{*}{ MP } & $\mathrm{Z} 1$ & 18 & $88(52)$ & $22(13)$ & 0.25 & 15 & $\begin{array}{c}49 \\
(32) \\
\end{array}$ & $14(9)$ & 0.29 & 15 & $25(9)$ & $10(6)$ & 0.41 \\
\hline & $\mathrm{Z} 2$ & 20 & $78(43)$ & $28(18)$ & 0.35 & 20 & $27(3)$ & 11 (1) & 0.41 & 17 & $24(3)$ & $14(3)$ & 0.56 \\
\hline & $\mathrm{Z} 3$ & 18 & $104(52)$ & $47(11)$ & 0.45 & 21 & $\begin{array}{c}65 \\
(18) \\
\end{array}$ & $33(7)$ & 0.52 & 13 & $\begin{array}{c}52 \\
(24) \\
\end{array}$ & $25(5)$ & 0.48 \\
\hline & $\mathrm{Z} 4$ & 16 & $53(48)$ & $13(5)$ & 0.25 & 17 & $\begin{array}{c}28 \\
(12) \\
\end{array}$ & $8(3)$ & 0.27 & 16 & $16(7)$ & $6(1)$ & 0.38 \\
\hline & $\mathrm{Z} 5$ & 15 & $54(13)$ & $17(6)$ & 0.32 & 13 & $33(8)$ & $10(2)$ & 0.29 & 14 & $21(5)$ & $9(2)$ & 0.45 \\
\hline & Z6 & 28 & $34(11)$ & $12(3)$ & 0.36 & 17 & $\begin{array}{c}39 \\
(11) \\
\end{array}$ & $13(2)$ & 0.34 & 17 & $22(6)$ & $9(1)$ & 0.42 \\
\hline \multirow{6}{*}{ EP } & $\mathrm{Z} 1$ & 17 & $94(86)$ & $33(51)$ & 0.35 & 18 & $\begin{array}{c}55 \\
(33) \\
\end{array}$ & $23(12)$ & 0.41 & 15 & $27(6)$ & $14(4)$ & 0.52 \\
\hline & $\mathrm{Z} 2$ & 30 & $137(41)$ & $33(10)$ & 0.24 & 21 & $\begin{array}{c}65 \\
(35) \\
\end{array}$ & $18(6)$ & 0.28 & 17 & $33(8)$ & $12(3)$ & 0.37 \\
\hline & $\mathrm{Z} 3$ & 24 & $146(87)$ & $29(10)$ & 0.20 & 25 & $\begin{array}{c}82 \\
(21) \\
\end{array}$ & $20(3)$ & 0.25 & 26 & $\begin{array}{c}45 \\
(10)\end{array}$ & 17 (4) & 0.38 \\
\hline & $\mathrm{Z4}$ & 14 & $61(21)$ & $25(13)$ & 0.41 & 16 & $\begin{array}{c}39 \\
(10) \\
\end{array}$ & $18(2)$ & 0.45 & 17 & $22(5)$ & $13(2)$ & 0.60 \\
\hline & $\mathrm{Z5}$ & 16 & $56(18)$ & $21(8)$ & 0.37 & 15 & $40(8)$ & $18(2)$ & 0.46 & 12 & $24(6)$ & $13(2)$ & 0.56 \\
\hline & Z6 & 19 & $43(11)$ & $22(11)$ & 0.52 & 16 & $41(7)$ & $22(7)$ & 0.53 & 17 & $27(9)$ & $14(2)$ & 0.53 \\
\hline
\end{tabular}




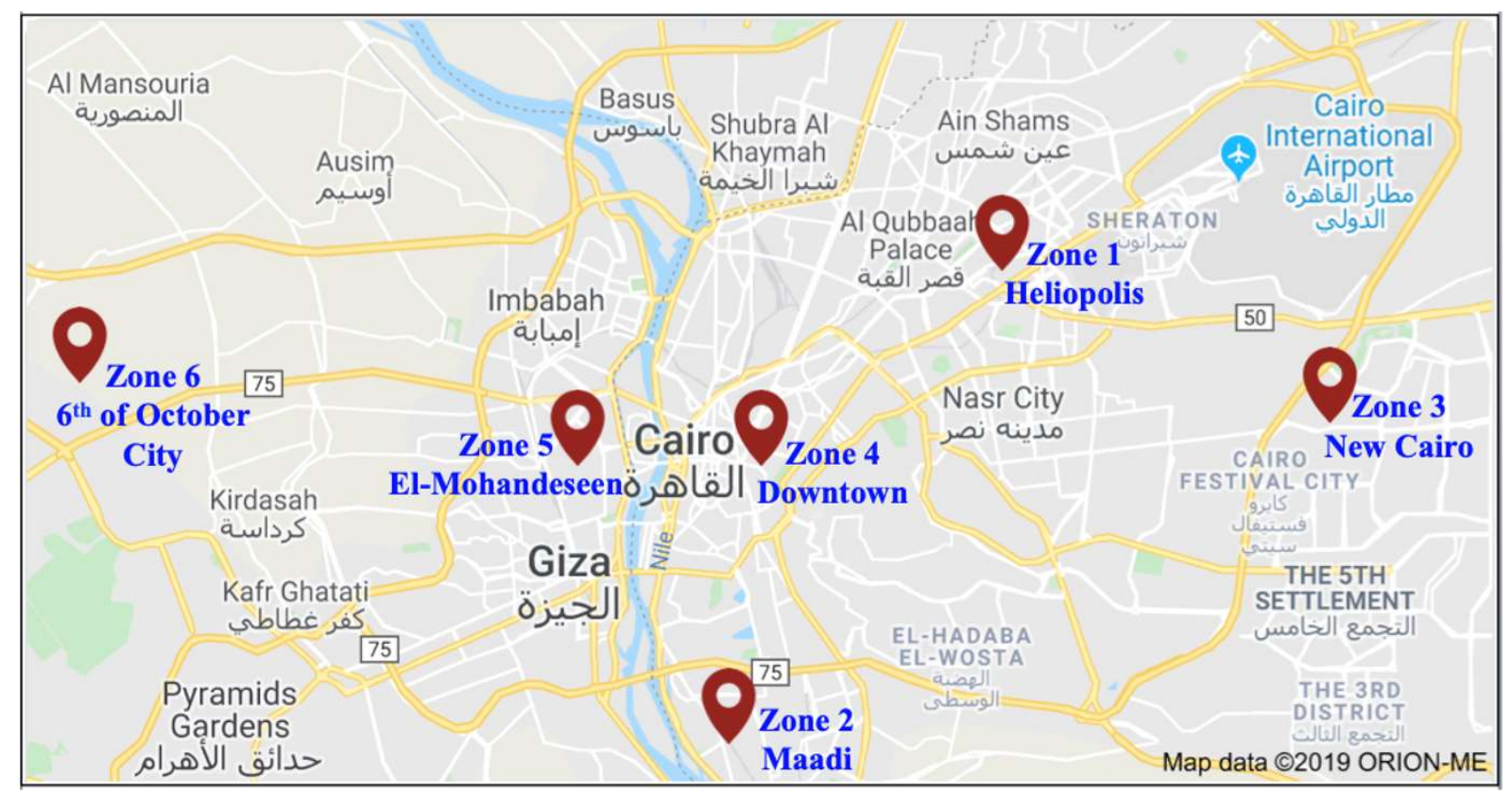

Figure 1. Map of Greater Cairo with the six high activity zones indicated. 

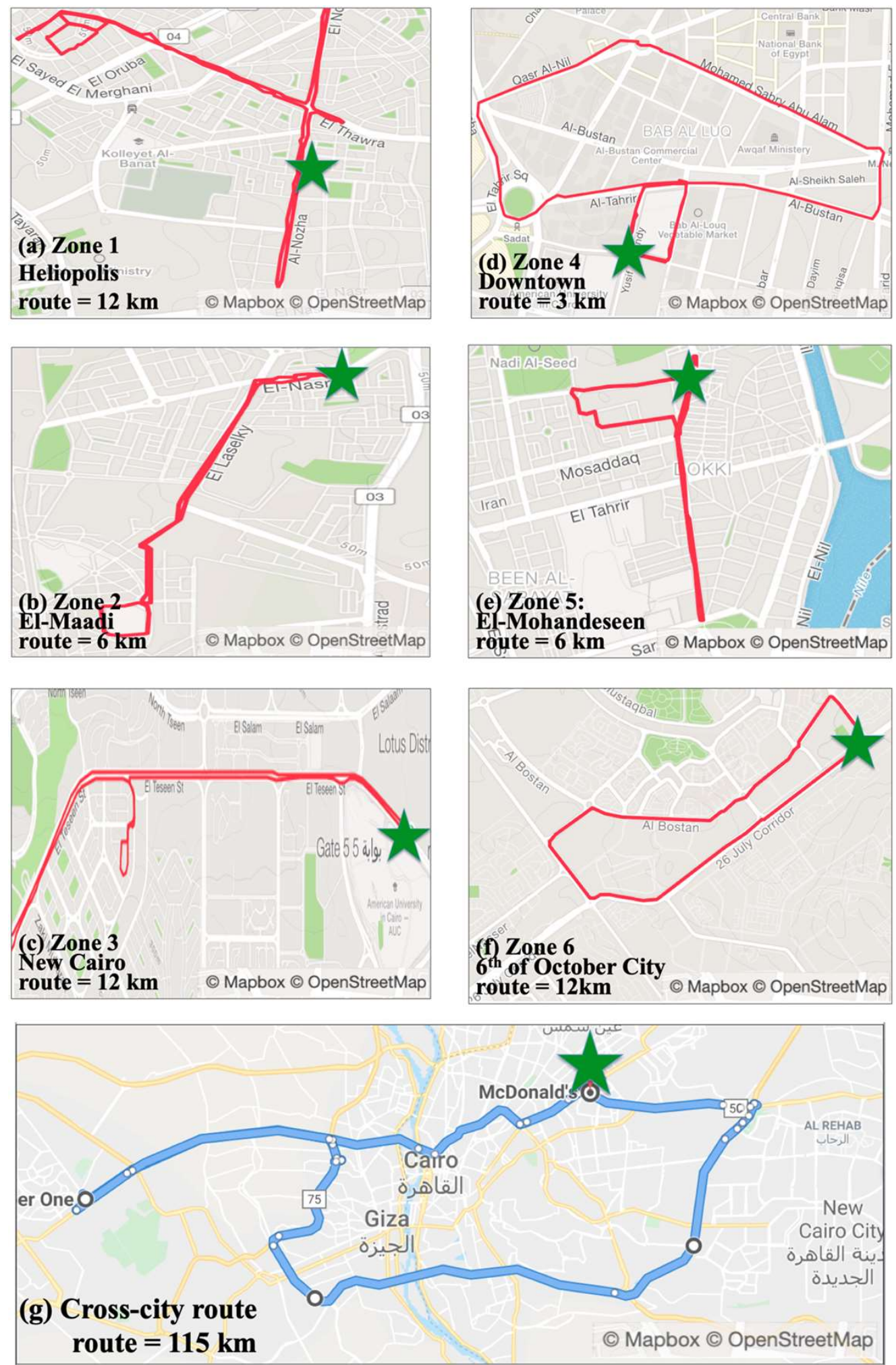

Figure 2. Maps of the selected routes by car for all zones. Maps (a)-(f) show the routes taken in each high-activity zone and map (g) shows the cross-city route. The red lines in maps (a)-(f) represent the routes, and the green star indicates the starting/end point. The blue line in mag (g) indicates the crosscity route in the last map. The zone name, number and the length of each route are shown on the bottom left of each map. 

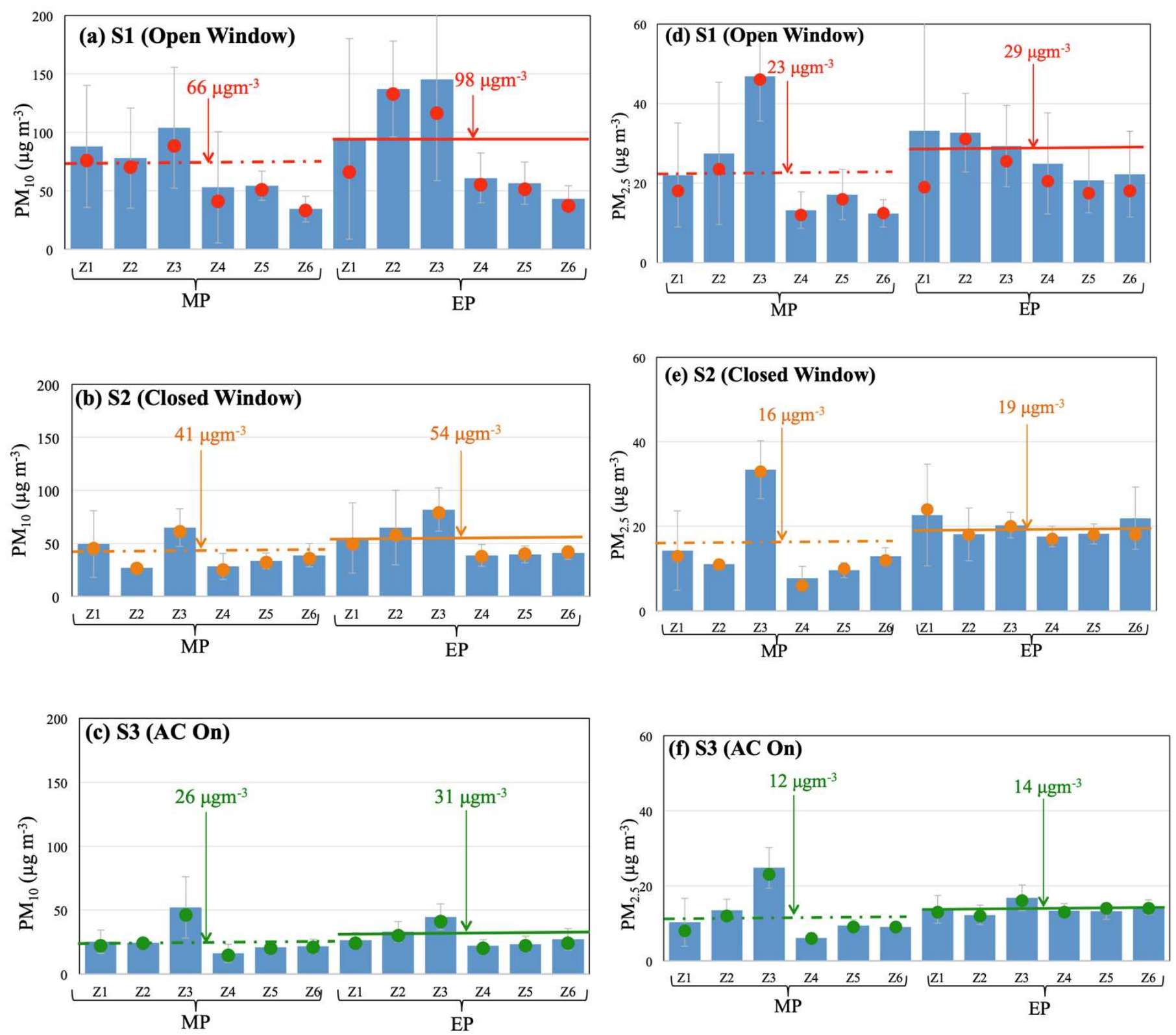

Figure 3. Bar charts showing the average PM concentrations for each zone and time of the day. The dots signify the median values for each session. The dashed horizontal line is the average PM concentration over the six zones with the values indicated in $\mu \mathrm{g} / \mathrm{m}^{3}$ during MP hours and the solid line represents the average over EP hours. The error bars represent the standard deviation for each of the MP and EP sessions. Charts (a), (b) and (c) depict $\mathrm{PM}_{10}$ concentration variations for S1, S2 and S3 while (d), (e) and (f) show $\mathrm{PM}_{2.5}$ concentration variations. 

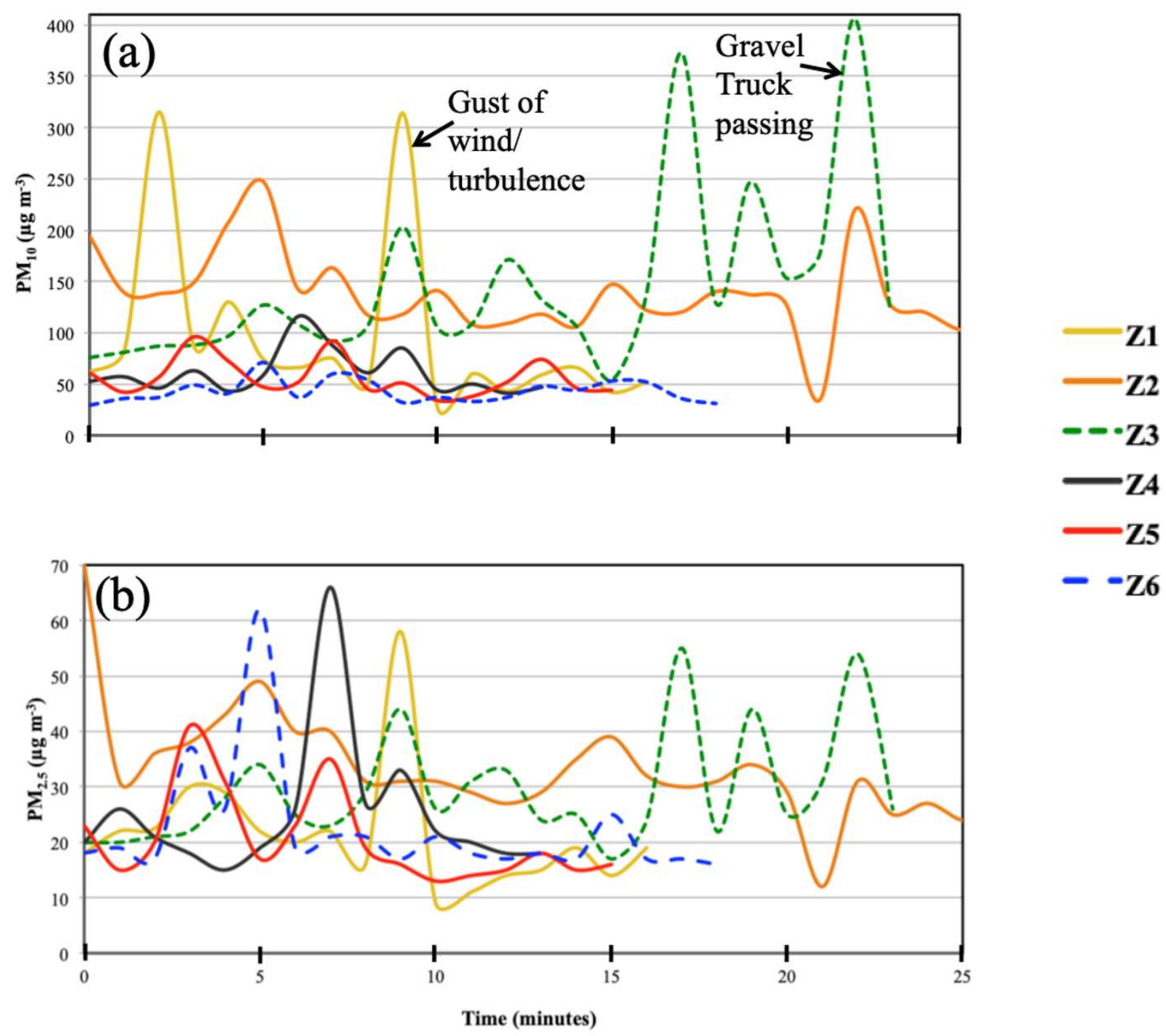

Figure 4. Open window evening peak (S1 EP) PM concentration plots versus time across the high-activity zones. Plot (a) demonstrates $\mathrm{PM}_{10}$ and (b) demonstrates $\mathrm{PM}_{2.5}$ fluctuations versus time. The different lines signify the six different zones as indicated in the legend on the right. 


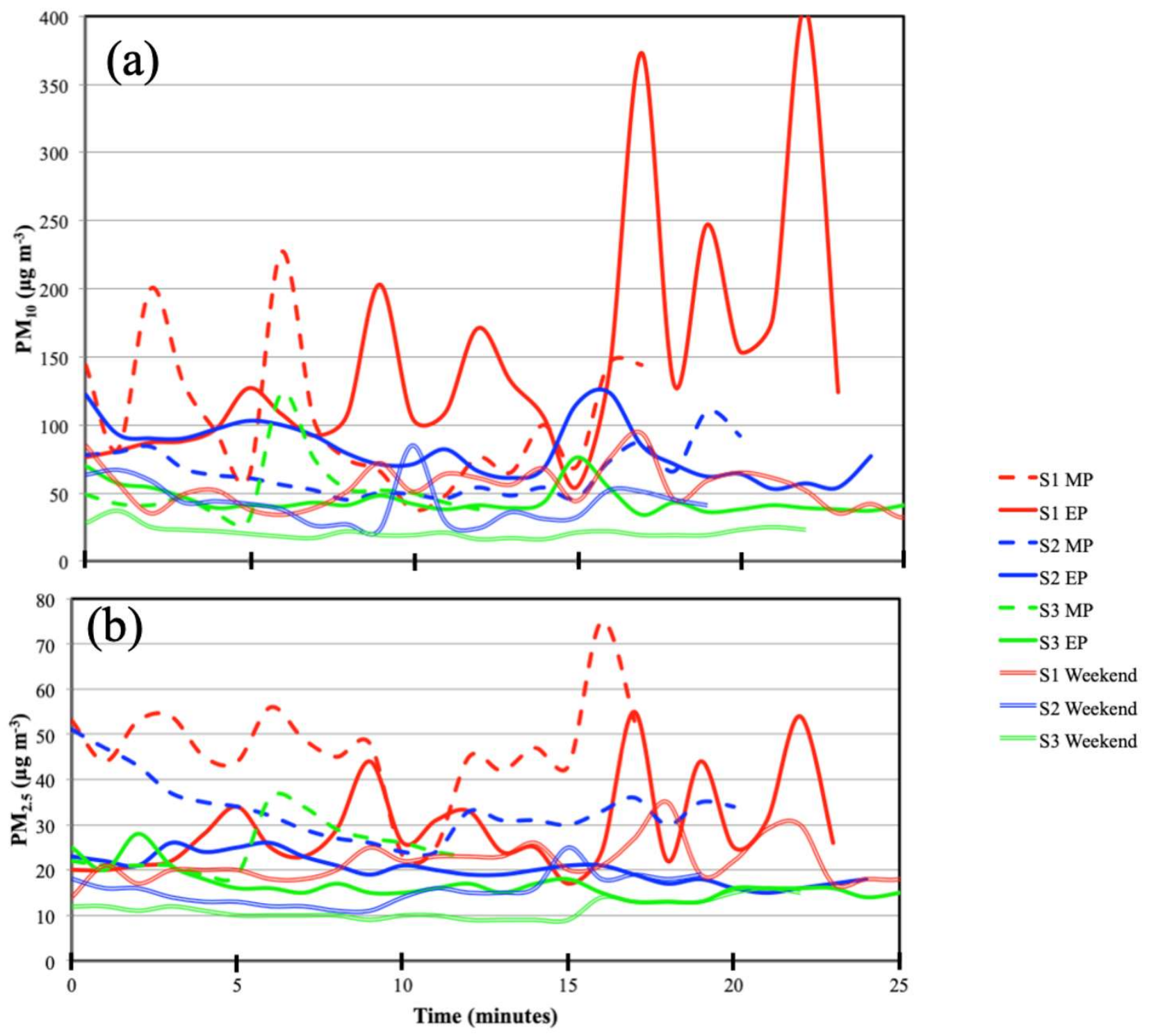

Figure 5. Z3 (New Cairo) PM concentrations plots versus time for all settings and times of the day and the weekend runs. Plot (a) illustrates $\mathrm{PM}_{10}$ and (b) shows $\mathrm{PM}_{2.5}$ concentration variations versus time for $\mathrm{Z} 3$ throughout all scenarios. The lines indicate the different scenarios as listed in the legend on the right. 

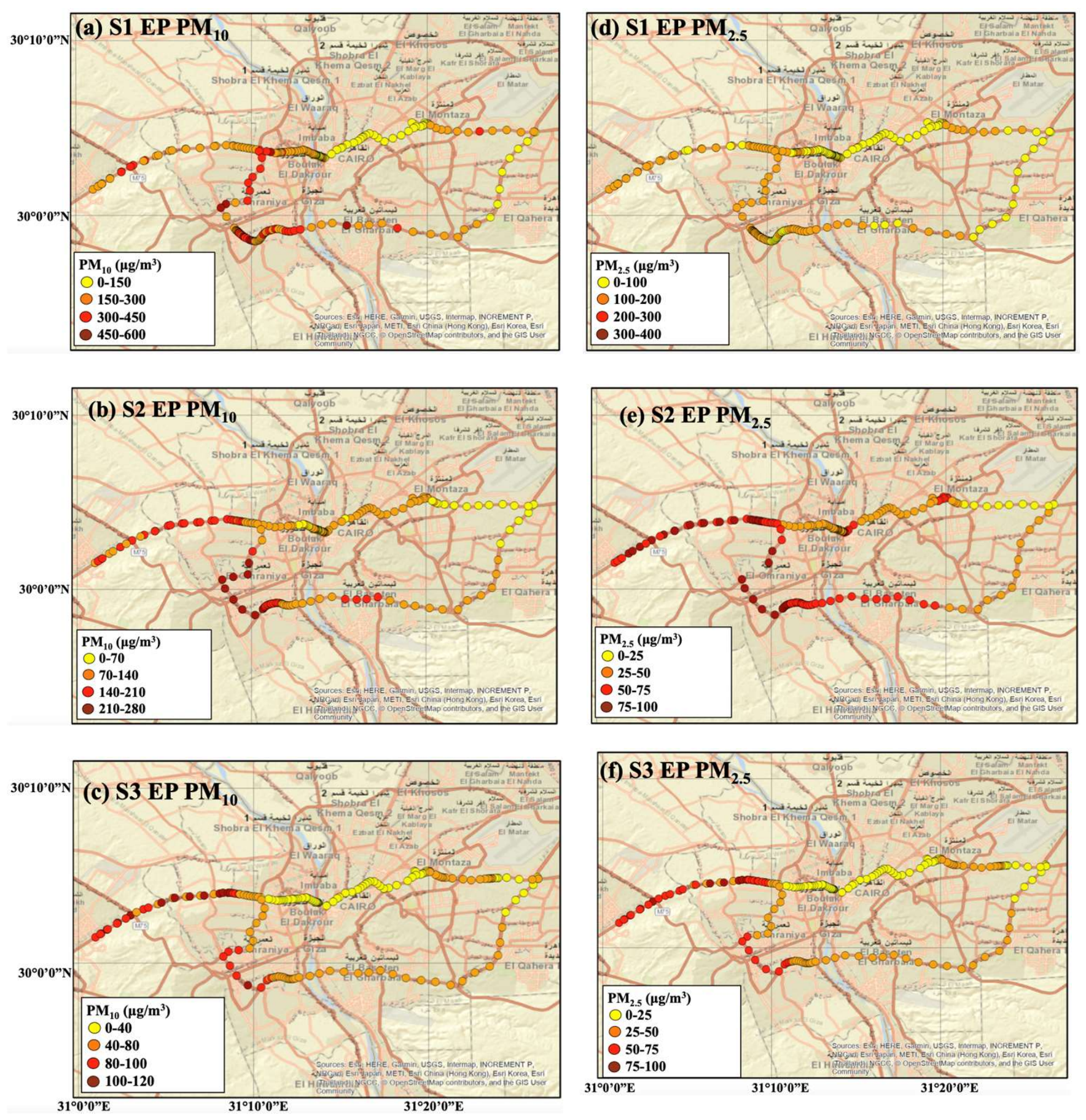

Figure 6. Spatial-concentration maps of cross-city route for the EP session. Maps (a), (b) and (c) depict $\mathrm{PM}_{10}$ concentration variations for S1, S2 and S3 throughout the cross-city trip while maps (d), (e) and (f) show $\mathrm{PM}_{2.5}$ concentration variations. The concentration ranges are set in colours on the bottom left of each map. Note that concentration ranges indicated in each legend differ from one map to another. 


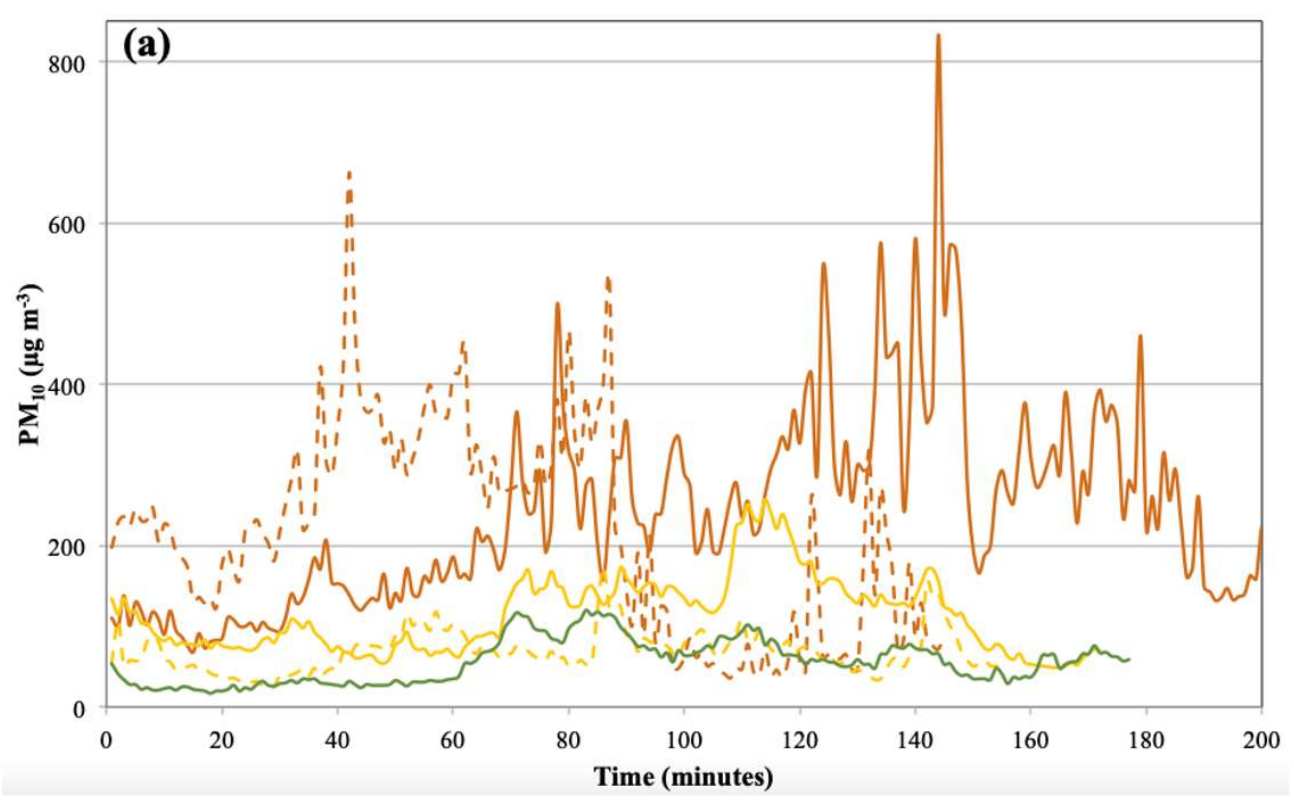

-- S1 MP

-S1 EP

$-{ }_{-} \mathbf{S 2}$ MP

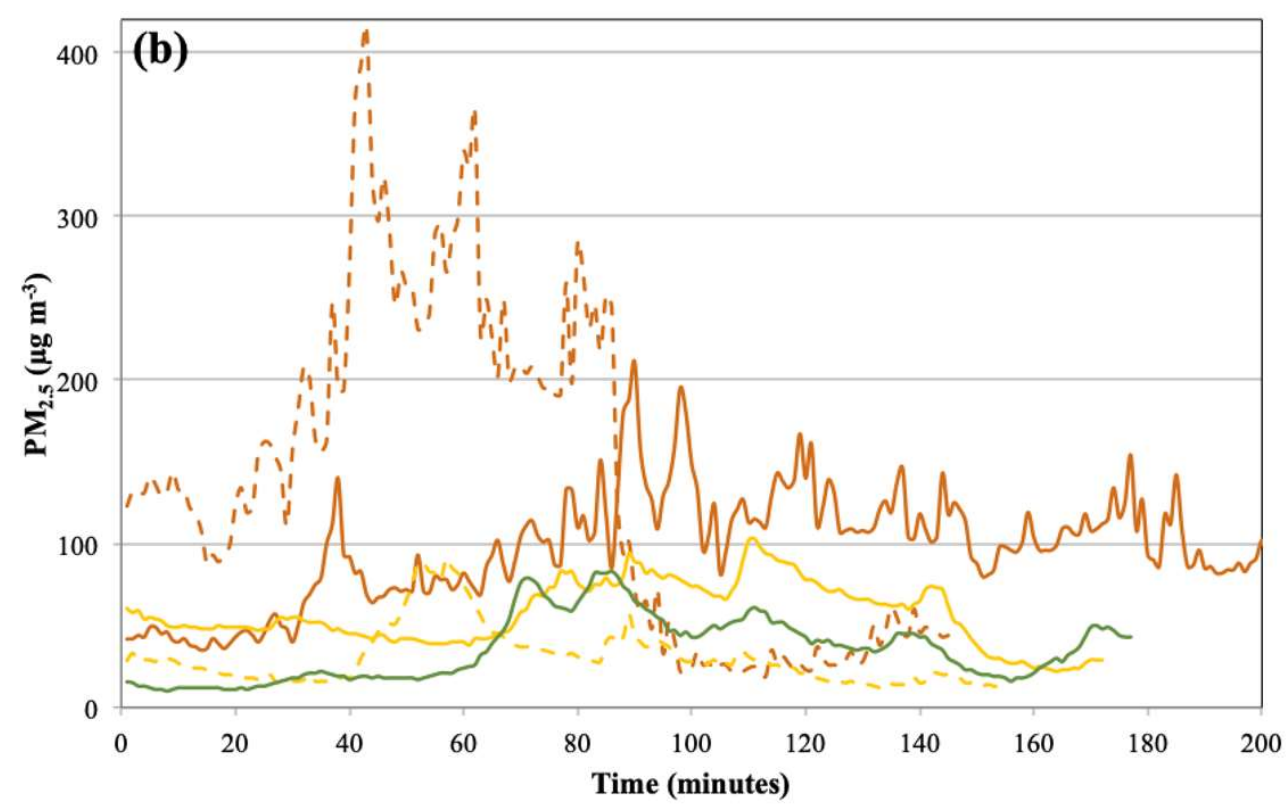

S2 EP

$-\mathrm{S3} \mathrm{EP}$

Figure 7. Concentration plots for cross-city route. Plot (a) shows $\mathrm{PM}_{10}$ concentration variations with time and plot (b) shows $\mathrm{PM}_{2.5}$. The legend on the right details the lines and the scenarios they represent. The S3 MP run has been compromised for both $\mathrm{PM}_{10}$ and $\mathrm{PM}_{2.5}$ and has hence been eliminated from plots and maps in Figure 7 and SI Figure S6 however, its concentration is expected to be close to $\mathrm{S} 3 \mathrm{EP}$ run concentration. 